\title{
6. EL TRATADO DE MAASTRICHT $Y$ EL DERECHO DE SUFRAGIO DE LOS EXTRANJEROS EN ESPAÑA
}

\author{
ARTEMI RALLO LOMBARTE \\ Profesor de Derecho Constitucional \\ Universidad Jaume l. Castellón
}


SUMARIO

INTROdUCCIÓN.-I. El Tratado de MAASTRICHT Y LOS ANTECEDENTES COMUNITARIOS.-A. Elecciones municipales. B. Elecciones europeas. - -l. EL DERECHO DE SUFRAGIO DE LOS EXTRANJEROS EN LOS EStados Miembros de la Comunidad Europea.-III. El dereCHO de SUFRAGIO DE LOS EXTRANJEROS EN ESPAÑA.-A. La reserva constitucional del art. 13 en favor de los españoles y su excepción: el consenso constituyente. B. Desarrollo legislativo del art. 13.2 de la Constitución.-IV. REFORMA CONSTITUCIONAL Y DERECHO DE SUFRAGIO DE LOS EXTRANJEROS.-A. ¿Es necesaria la reforma constitucional? Tres posiciones doctrinales. B. La titularidad de derechos políticos. El art. 23 de la Constitución. C. Una propuesta alternativa de reforma constitucional. 


\title{
6. EL TRATADO DE MAASTRICHT Y EL DERECHO DE SUFRAGIO DE LOS EXTRANJEROS EN ESPAÑA ${ }^{1}$
}

\author{
POR \\ ARTEMI RALLO LOMBARTE \\ Profesor de Derecho Constitucional \\ Universidad Jaume I. Castellón
}

\section{INTRODUCCIÓN}

El art. 8B del Tratado de Unión Europea acordado el 10 de diciembre de 1991 en Maastricht (Holanda) por la cumbre de Jefes de Estado y de Gobierno de la Comunidad Europea reconoce a los «ciudadanos europeos" residentes en un Estado miembro que sean nacionales de otro Estado miembro de la Comunidad el derecho de sufragio activo y pasivo en las elecciones municipales y europeas del Estado en que residan.

El reconocimiento de este derecho constituye la culminación de numerosas resoluciones del Parlamento Europeo y de los trabajos previos de la Comisión, asi como del análisis de similares experiencias desarrolladas en varios Estados europeos. En nuestro país, no obstante, ha abierto la polémica sobre la necesidad o no de reforma constitucional por cuanto el art. 13.2 reserva a los españoles la titularidad de los derechos previstos en el art. 23 del texto constitucional, salvo el derecho de sufragio activo en las elecciones municipales que podrá ser ejercido por los extranje-

1 Resulta obligado agradecer a la Universidad Jaume I de Castellón la concesión de la beca de investigación que hizo posible la estancia del autor de este trabajo en la Dirección General de Estudios del Parlamento Europeo en Luxemburgo durante enero y febrero de 1992, sin la cual hubiese resultado difícil obtener los materiales necesarios para la elaboración del mismo. 
ros de acuerdo con el principio de reciprocidad y lo que prevean tratados $y$ leyes.

Este trabajo pretende contribuir al análisis en curso sobre la necesidad o no de la reforma constitucional y a ofrecer propuestas partiendo del estudio de la voluntad constituyente acerca de la exclusión del derecho de sufragio de los extranjeros en España, del desarrollo legislativo de nuestra Carta magna, de las posturas doctrinales expuestas hasta la fecha y de conceptos jurídicos vinculados al derecho de sufragio.

\section{EL TRATADO DE MAASTRICHT Y LOS ANTECEDENTES COMUNITARIOS}

Reunido el Consejo Europeo en Maastricht (Holanda) durante el 9 y 10 de diciembre de 1991, los Jefes de Estado y de Gobierno de los países de la Comunidad Europea ultimaron el contenido del Tratado sobre la Unión Política que sería firmado durante el mes de febrero de 1992 por los Estados Miembros ${ }^{2}$.

La segunda parte del mencionado Tratado crea la ciudadanía de la Unión que se atribuye a toda persona que ostente la nacionalidad de un Estado miembro y a la que se le reconoce la titularidad de los derechos y deberes previstos en el Tratado (art. 8). Entre éstos destaca el derecho a circular y residir libremente en el territorio de los Estados miembros con sujeción a las limitaciones y condiciones previstas en el Tratado y en las disposiciones adoptadas para su aplicación por el Consejo (art. 8 A).

El artículo $8 \mathrm{~B}$ del Tratado establece que todo ciudadano de la Unión que resida en un Estado miembro del que no sea nacional tendrá derecho a ser elector y elegible en las elecciones municipales y europeas del Estado miembro en el que resida en las mismas condiciones que los nacionales de dicho Estado. Este derecho se ejercerá sin perjuicio de las modalidades que el Consejo deberá adoptar antes del 31 de diciembre de 1994 (municipales) o de 1993 (europeas), por unanimidad, a propuesta de la Comisión y previa consulta al Parlamento ${ }^{3}$; dichas modalidades po-

2 Traité sur I'union politique. Europe Documents, Agence Internationale d'information pour la presse, Bruxelles, núm. 1750/1751, 13 de décembre de 1991, págs. 1 a 29. En versión española, Tratado de la Unión Europea, Comisión de las Comunidades Europeas, Oficina en España.

3 Hay que resaltar que, a diferencia de la ciudadanía, la intervención del Parlamento Europeo en materia de participación de los ciudadanos comunitarios 
drán establecer excepciones cuando asi lo justifiquen problemas específicos de un Estado miembro ${ }^{4}$.

La incorporación de estas disposiciones al Tratado de Maastricht constituye el final de un largo camino iniciado por las instituciones comunitarias en pro del reconocimiento de estos derechos pero, al mismo tiempo, es el punto de partida para el desarrollo de los mismos por las disposiciones que emanen del Consejo, a propuesta de la Comisión y previa consulta del Parlamento, antes del 1 de enero de 1994 y 1995. A fin de aventurar el contenido de las mismas, vamos a exponer los trabajos previos realizados por estas instituciones diferenciando el tratamiento de las elecciones municipales europeas.

\section{A. Elecciones municipales}

El 8 de julio de 1988 la Comisión de las Comunidades Europeas presentó al Consejo una propuesta de Directiva del Consejo sobre el derecho de sufragio de los nacionales de los Estados miembros en las elecciones municipales en el Estado miembro de residencia ${ }^{5}$ que, atendiendo a los precedentes que la impulsaron ${ }^{6}$, fundamentaba el reconocimiento de este derecho en los siguientes argumentos:

en las elecciones locales y europeas adquiere la dimensión de consulta y no de dictamen conforme (Première analyse du Conseil Européen de Maastricht, Direction Général des Études, Division des Affaires politiques et institutionnelles, Luxembourg, le 6 de janvier 1992, pág. 4).

4 Esta previsión del Tratado ya se contenía, en términos similares, en los documentos preparatorios: Project d'articles de traité, en vue de la mise en place d'une union politique, Europe Documents, Agence Internationale d'information pour la presse, Bruxeles, núm. 1709/1710, 3 mai 1991, pág. 4. Union politique: la structure du projet de traité. Contribution de la Commission Européenne à la Conference Intergouvernementale, Europe Documents, Agence International d'information pour la presse, Bruxelles, núm. 1715, 31 mai 1991, página 4. Project de traité sur I'union, Europe Documents, Agence Internationale d'information pour la presse, Bruxelles, núm. 1722/1723, 5 juillet 1991, págs. 4 y 5 . Le project neerlandais de traité vers l'union européenne, Europe Documents, Agence International d'information pour la presse, Bruxelles, núm. 1733/ 1734, 3 octobre 1991, pág. 3. Projet de traité sur l'union (document de travail de la Presidence neerlandaise), Europe Documents, Agence International d'information pour la presse, núm. 1746/1747, 20 novembre 1991, págs. 4 y 5.

5 Documentos de Sesión, Parlamento Europeo, Comunidades Europeas, C2-0104/88, COM/88/371, serie C, 10 de agosto de 1988.

6 En 1974 los Jefes de Estado y de Gobierno de la CEE encargaron el estudio de la concesión de derechos a los nacionales de los Estados miembros y, como consecuencia, la Comisión en 1975 propuso que entre éstos se atendiese al dere- 
- El art. 235 TCEE habilita al Consejo para que, a propuesta de la Comisión y previa consulta a la Asamblea, adopte las disposiciones pertinentes cuando una acción de la Comunidad resulte necesaria para lograr, en el funcionamiento del mercado común, uno de los objetivos de la Comunidad, sin que el Tratado haya previsto los poderes de acción necesarios ${ }^{7}$.

- El art. 3 c) TCEE dispone que, para lograr los fines atribuidos a la comunidad, su acción llevará consigo la supresión, entre los Estados miembros, de los obstáculos a la libre circulación de personas.

- El art. 8 A TCEE establece que la Comunidad adoptará las medidas destinadas a establecer progresivamente un espacio sin fronteras interiores en el que la libre circulación de personas estará garantizada de acuerdo con las disposiciones del Tratado.

- La incongruencia que supone la privación del derecho de sufragio municipal por no residir en el Estado miembro cuya nacionalidad se posee en una Comunidad que agrupa a Estados cuya principal característica es la de ser democráticos y cuyo Tratado constitutivo consagra la libertad de circulación de personas ${ }^{8}$.

cho de sufragio de los nacionales de los Estados miembros que residiesen en países distintos al de origen en las elecciones municipales. Esta idea obtuvo el apoyo del Consejo Europeo de Fontainebleau de junio de 1984, del Consejo Europeo de Milán y del Parlamento Europeo en sus resoluciones de 8 de junio de 1983 y de 13 de noviembre de 1985 (D.O. núm. C 184, de 11 de agosto de 1983 y $D . O$. núm. C 345, de 31 de diciembre 1985). El 7 de octubre de 1986 la Comisión remitió al Consejo y al Parlamento un informe descriptivo de la situación de los Estados miembros ante la adopción de posibles acuerdos sobre la materia y el Parlamento, tras nombrar ponentes a Oscar Vetter de la Comisión Jurídica y a Robles Piquer de la Comisión Política, adoptó el 15 de diciembre de 1987 una nueva resolución de apoyo.

7 La elección de la Directiva como instrumento jurídico resulta necesaria por razones funcionales puesto que ésta es la única norma jurídica que posee la fuerza jurídica necesaria para que se aplique y permite a cada Estado miembro proceder, antes de la transposición en derecho interno, a las modificaciones constitucionales necesarias (sin olvidar que el Tribunal de Justicia ha afirmado la primacía del derecho comunitario sobre el derecho constitucional interno, entre otras, en sus sentencias de 22 de junio de 1965, de 15 de julio de 1964 o de 9 de marzo de 1978) y, además, esta reforma sólo puede aplicarse en la Comunidad si se funda en una aplicación idéntica a todos los ciudadanos de los Estados miembros sin crear desigualdades entre los ciudadanos europeos.

8 "Néanmoins ce droit de vote constitue un corollaire indispensable du droit de circulation et d'établissement du citoyen européen" (Première analyse du Conseil Européen de Maastricht..., pág. 7). 
- El establecimiento de una Europa de los ciudadanos debe provocar la desaparición de las discriminaciones de los nacionales de un Estado miembro que residen en otro. A tal fin el criterio de residencia resulta más adecuado que el de nacionalidad para determinar el lugar del voto por cuanto la pertenencia real a un Ayuntamiento se deriva de cuestiones de condición de vida cotidiana tributarias de las decisiones del órgano colegiado que lo dirige (problemas escolares, de urbanismo, impuestos locales).

- La integración en la actividad económica y social del país de acogida es superior si se disfrutan de derechos idénticos a los de los nacionales.

La mencionada Propuesta de Directiva reconocía el derecho de sufragio de los nacionales de los Estados miembros en las elecciones municipales en el Estado miembro de residencia de conformidad con las siguientes notas:

- Los Estados miembros conceden a los nacionales de los restantes Estados miembros que disfruten de los derechos civiles inherentes a dicha nacionalidad y que residan de forma regular en su territorio el derecho al sufragio activo, universal y directo, $y$ al sufragio pasivo en las elecciones municipales en el municipio en que residan, es decir, para la elección de los órganos (Corporaciones o alcaldes de los municipios) investidos, con arreglo a las normas de la legislación interna, de los poderes para gestionar y administrar el primer escalón de la organización política y administrativa ${ }^{\text {. }}$.

$9 \quad$ En la defensa de esta premisa señalará el eurodiputado Vetter: «En el origen de la democracia figura la exigencia de libertad, y a la libertad pertenece el libre derecho de autodeterminación. El medio específico es la cooperación de todos, cuando se trata de elegir a los mandatarios que han de ejercer el poder. Esta libertad se ha ido constituyendo sólo paulatinamente a través de un proceso histórico en los Estados europeos, pues primero fueron los contribuyentes, los propietarios, luego, los trabajadores $y$, finalmente, las mujeres quienes consiguieron este derecho. Hoy luchan por este derecho los miembros de la Comunidad Europea que han elegido su punto central de subsistencia en un país distinto al de su nacionalidad" (Diario Oficial de las Comunidades Europeas, Debates del Parlamento Europeo, núm. 2-376, 14 de marzo 1989, pág. 80). En el mismo sentido el eurodiputado Barzanti: "Estamos hablando de un derecho, no de una concesión. Mediante su participación en las elecciones municipales, quienes han tenido que dejar su país de origen se sentirán miembros de un municipio, de una colectividad que es la suya y que constituye la célula básica de nuestras democracias...es oportuno recordar la descripción que de un mítico Estado hizo el gran escritor Robert Musil: "Allí todos los ciudadanos eran iguales frente a la ley, pero no todos eran ciudadanos" (Diario 
- Los nacionales de los Estados miembros que quieren hacer uso de estos derechos deberán presentar una solicitud de inscripción en el censo electoral municipal ante las autoridades responsables de los comicios, que tienen un deber de información idéntico que con sus nacionales, y presentarán una certificación del Consulado de su Estado miembro de origen de que no han sido privados de sus derecho civiles y de que ya no ejercen dicho derecho en su Estado de origen.

- Esta inscripción podrá solicitarse transcurrido un período de residencia ininterrumpida de una duración máxima igual al mandato de una Corporación municipal.

- Se les aplicará, en las mismas condiciones que a los nacionales, la legislación interna del Estado miembro de residencia en materia de edad mínima, incapacidades u obligaciones como, en particular, el voto obligatorio.

- El derecho al sufragio pasivo podrá ejercerse transcurrido un período de residencia ininterrumpida en el Estado miembro de acogida de una duración igual como máximo a dos mandatos de una Corporación municipal $y$ en las mismas condiciones que los nacionales en materia de edad mínima, incompatibilidades e inelegibilidades.

- No obstante, los Estados miembros podrán impedir que los nacionales de los restantes Estados miembros ejerzan funciones de alcalde, teniente de alcalde o equivalente, que -cuando los miembros de una Corporación municipal sean por ello electores de una Asamblea parlamentaria o cuando los miembros de una Corporación municipal nombren entre sus miembros a los electores de una Asamblea parlamentaria- no puedan participar en dicha elección y que, cuando la proporción de nacionales de los Estados miembros que residan en otro Estado miembro sea superior al 20 por 100 de la población total, pudiera no aplicarse la Directiva en las primeras elecciones generales que se celebrasen tras su entrada en vigor. Igualmente los Estados miembros podrían prever que durante las dos primeras elecciones generales no superasen una proporción de una cuarta parte del número total de miembros de la Corporación ${ }^{10}$.

Oficial de las Comunidades Europeas, Debates del Parlamento Europeo, núm. 2376, 14 de marzo 1989, pág. 82).

10 En éste último supuesto sólo se considerarían elegidos, en el caso de una votación uninominal o con una lista de preferencia, los que hubiesen obtenido mayor número de votos dentro del límite del 25 por $100 \mathrm{y}$, en el caso de un escrutinio por listas, según el orden de presentación en la lista. 
El 8 de septiembre de 1988 el Parlamento Europeo adoptó sendas nuevas resoluciones ", a propuesta de los Grupos Popular Europeo y Comunistas y afines, para eliminar las normativas administrativas nacionales que son obstáculo para el ejercicio efectivo del derecho del ciudadano a la libertad de circulación, de establecimiento y de residencia subrayando la urgencia de posibilitar la participación en las elecciones municipales del ciudadano de un Estado miembro que resida en otro bajo determinadas condiciones (por ejemplo reciprocidad, estancia mínima) y teniendo en cuenta las respectivas competencias municipales.

El 14 de marzo de 1989 los eurodiputados Vetter, en nombre de la Comisión de Asuntos Jurídicos y de Derechos de los Ciudadanos, y Marinaro, de la Comisión de Asuntos Sociales y de Empleo, informaban al Pleno del Parlamento sobre la mencionada propuesta de Directiva de la Comisión al Consejo ${ }^{12}$.

El informe Vetter reconocía el derecho al sufragio activo y pasivo en las elecciones municipales, en el Estado miembro de residencia, a los nacionales de otros Estados miembros que residan ininterrumpidamente por un período de tiempo no superior a cinco años, remitía el concepto de "elección municipal" a la que realizasen los Estados miembros y amplió la excepción de aplicación de la Directiva cuando la proporción de nacionales de los Estados miembros que residan en otro Estado miembro sea superior a un 20 por 100 de la "población electoral total».

El informe Marinaro recomendaba a los Estados miembros, a fin de conseguir una Comunidad que excluyese cualquier discriminación, prever la ampliación del derecho de sufragio en las elecciones municipales a los emigrantes procedentes de terceros países (como es el caso de Dinamarca, Irlanda y los Países Bajos) ${ }^{13}$, limitaba la exclusión de los nacionales de

11 Documentos de Sesión, Parlamento Europeo, Comunidades Europeas, B 2-676/88, serie B, 8 de septiembre y B2-675/88, serie B, 8 de septiembre de 1988 .

12 Documentos de Sesión, Parlamento Europeo, Comunidades Europeas, A2-0392/88, serie A, 9 de febrero de 1989.

${ }_{13}$ De interés resultan las intervenciones realizadas durante el debate del Informe VETTER por los europarlamentarios Marinaro - "Esta igualdad es cada vez más necesaria para alcanzar un grado más alto de convivencia y de civilización en la Europa de hoy y mañana, y para combatir eficazmente las escandalosas y bárbaras campañas xenófobas y racistas que acentúan la marginación de los inmigrantes» - Van Der Lek y Ulburghs - "Es inadmisible que una parte de los inmigrantes obtenga el derecho de sufragio y la otra parte no..., las personas débiles se ven enfrentadas entre sí...El derecho de sufragio saca a la persona débil de su marginalidad, del desprecio en que se ve sumida, de la caridad, y le concede derechos....- (Diario Oficial de las Comunidades Europeas, Debates del Parlamento Europeo, núm. 2-376, 14 de marzo 1989, págs. 81, 83 y 84). 
los restantes Estados miembros del ejercicio de las funciones de alcalde $y$ de teniente de alcalde a los supuestos de que estos cargos estuviesen relacionados con tareas jurisdiccionales que sobrepasasen el ámbito municipal y de la participación en la elección de una Asamblea parlamentaria, establecía la inscripción de oficio en el censo electoral de éstos y preveía un período de residencia, no necesariamente ininterrumpida, en el Estado miembro de acogida de una duración máxima igual al mandato de una Corporación municipal ${ }^{14}$.

El 25 de enero de 1989 el Comité Económico y Social aprobó un Dictamen sobre la propuesta de Directiva del Consejo ${ }^{15}$ observando que el derecho de sufragio en las elecciones municipales en el Estado y lugar de residencia constituye un derecho inalienable de libre elección del ciudadano y no una obligación, que el período mínimo de residencia debería ser idéntico tanto para el derecho de sufragio activo como para el pasivo, que la limitación del número de concejales originarios de otros países podría quebrantar el art. 3 del protocolo anexo a la Convención europea sobre derechos humanos ${ }^{16}$ y que debería solucionarse el problema de la participación de los ciudadanos de la CEE en las elecciones intermedias (circunscripciones, provincias, regiones, etc.), el de la ampliación del derecho de

14 Tampoco faltaron, no obstante, las voces discrepantes con los informes. Entre ellas destacamos las de los eurodiputados Guermeur, Palmieri, quien consideró el informe inserto en "el proceso que las instituciones europeas llaman la Europa de los ciudadanos y que nosotros llamamos la Europa de la decadencia» - "...estimamos que el derecho de voto debe estar vinculado a la nacionalidad. Las leyes constitucionales en vigor garantizan este privilegio. Además, el hecho de ser elegible afecta directa o indirectamente a otros mandatos electivos. El hecho de querer eliminar la distinción entre nacionales y extranjeros resulta peligroso y puede llevarnos posteriormente a una ampliación del derecho de voto a otros tipos de elecciones y a los naturales de terceros países... Más que nunca debemos permanecer vigilantes y denunciar la desviación suicida de este Parlamenton- y Pirkl - "Queremos crear una Europa que esté construida sobre el principio de la subsidiaridad. Lo que no ha de ser regulado necesariamente por la $\mathrm{CE}$, habría que dejarlo en el ámbito de la competencia nacional...el derecho de sufragio está inseparablemente unido a la nacionalidad y, sobre todo, a las obligaciones que se derivan de ella. El derecho de sufragio en las elecciones municipales no es un derecho de sufragio de segundo orden que se pueda desvincular arbitrariamente de los demás derechos y obligaciones de la nacionalidad"-(Diario Oficial de las Comunidades Europeas, Debates del Parlamento Europeo, núm. 2-376, 14 de marzo 1989, páginas 83 y 87 ).

15 Diario Oficial de las Comunidades Europeas, núm. C71, 20 de marzo de 1989, págs. 2 a 8.

16 Art. 3 Protocolo adicional al Convenio para la Protección de los Derechos Humanos y de las Libertades Públicas: "Las Altas Partes Contratantes se comprometen a organizar, a intervalos razonables, elecciones libres con escrutinio secreto, en condiciones que aseguren la libre expresión de la opinión del pueblo acerca de la elección del cuerpo legislativo". 
sufragio a los refugiados, apátridas y, en general, a los ciudadanos de terceros países ${ }^{17}$.

El 15 de marzo de 1989 el Parlamento Europeo aprobó la propuesta de la Comisión ${ }^{18}$ si bien invitándola a modificarla, incluyendo las enmiendas aprobadas por éste relativas, tanto para el sufragio activo como pasivo, a un período mínimo de residencia de un máximo de cinco años, al entendimiento como «elección municipal» la que defina así cada Estado miembro y a la delimitación del límite del 20 por 100 a los electores inscritos en el censo electoral ${ }^{19}$.

Si bien la Carta de Derechos Fundamentales que el Parlamento Europeo hubiera deseado insertar en el Tratado de Maastricht va mucho más lejos que el mero reconocimiento del derecho de ciudadanía ${ }^{20}$, la incorporación del derecho de sufragio de los ciudadanos europeos residentes en Estados miembros de los que no son nacionales recoge las aspiraciones manifestadas en su Resolución de 12 de diciembre de 1990 sobre los fundamentos constitucionales de la Unión Europea ${ }^{21 .}$

17 En su sesión del 10 y 21 de abril el Comité Ejecutivo de la Confederación Europea de Sindicatos aprobó una resolución sobre "La Europa de los ciudadanos y el derecho de voto de los emigrantes de los Estados miembros en las elecciones municipales del Estado miembro de residencia" que apoyaba la propuesta de Directiva si bien reivindicaba similar período de residencia para el derecho de sufragio activo y pasivo, la supresión de exclusión del acceso a los cargos de alcalde o de primer teniente de alcalde y el límite del 25 por 100 en la composición de la Corporación municipal, que el límite del 20 por 100 de la población se interpretase sobre el municipio y no sobre el Estado y sobre la población inscrita en el censo electoral $y$, por último, que este derecho se extendiese a los residentes de países no comunitarios y que se examinase el problema de la participación de los ciudadanos comunitarios en las elecciones intermedias en provincias, regiones, etc. (Confédération européenne des syndicats: "L'Europe des citoyens et droit de vote des ressortissants des Etats membres aux elections municipales dans l'Etat membre de residence", Bruxelles, CES, 20-21 avril 1989).

18 Gazzetta ufficiale delle Comunità europee, núm. C 96, 17.4.89, págs. 101 a 107.

19 A resultas de este largo proceso la Comisión modificó la propuesta de Directiva el 23 de octubre de 1989 interpretando por elecciones municipales las que definiese como tales cada Estado miembro y no considerando como interrupción de residencia la ausencia por vacaciones o motivos de fuerza mayor (Diario Oficial de las Comunidades Europeas, núm. C 290, 18 de noviembre 1989, págs. 4 a 10).

20 Première Analyse du Conseil Européen de Maastricht..., pág. 7.

21 1993, LOS NUEVOS TRATADOS, Las propuestas del Parlamento Europeo, Parlamento Europeo, Luxemburgo, 1991, pág. 62.

Igualmente estos derechos se hallan implícitos en La Declaración sobre los Derechos de Libertades Fundamentales aprobada por el Parlamento el 12 de abril de 1989 ( $D O C 120$ de 16 de mayo de 1989, pág. 51) y el Informe previo a ésta de la 


\section{B. Elecciones europeas}

El art. 138 de la quinta parte del Tratado de Maastricht, en consonancia con el art. 138.3 TCEE y el art. 7.1 del Acta del Parlamento Europeo de 20 de septiembre de 1976 sobre la elección de representantes al Parlamento Europeo por sufragio universal directo ${ }^{22}$, establece que el Parlamento Europeo elaborará proyectos encaminados a hacer posible su elección por sufragio universal directo de acuerdo con un procedimiento uniforme en todos los Estados miembros, para lo cual, el Consejo establecerá por unanimidad, previo dictamen conforme del Parlamento Europeo, que se pronunciará por mayoría de sus miembros, las disposiciones pertinentes y recomendará a los Estados miembros su adopción de conformidad con sus respectivas normas constitucionales ${ }^{23}$.

Comisión de Asuntos Institucionales (INFORME DE GUCHT, FERRER I CASALS, ROTHLEY, VALVERDE LÓPEZ y FILINIS, Documentos de Sesión, Parlamento Europeo, Comunidades Europeas, A2-3/89/Parte A y B, de 20 de marzo de 1989). Inexplicablemente el segundo Informe provisional COLOMBO sobre los fundamentos constitucionales de la Unión Europea ha suprimido la referencia expresa de este derecho (Documentos de Sesión, Parlamento Europeo, Comunidades Europeas, A3-301/90, de 12 de noviembre de 1990).

22 Journal officiel des Communautés européenes, núm. L 278, de 8 de octubre de 1976, pág. 6 .

23 Sobre la posición de la doctrina extranjera acerca del procedimiento electoral uniforme en el Parlamento Europeo, véase: F. LANCHESTER: «Instituzioni europee. Parlamento europeo: el progetto di procedura elettorale uniforme", Quaderni Constituzionali, a. VII, núm. 1, aprile 1987, págs. 149 a 154. G. RatTo: $A$ uniform electoral system: Consequences for the representativeness and powers of the European Parliament. European Parliament Library, Dicember, 1990. G. Vedovato: "Legge elettorale europea uniforme", Rivista d'Studi Politici Internazionali. Firenze, núm. 204, octubre-diciembre 1984, págs. 609 a 615. G. SALIMBENI: «La legge elettorale europea: Un problema di uniformità, Affari sociali internazionali, núm. 1, 1984, págs. 211 a 219. M. SilveStRo: "L'élection des membres du Parlement européen au suffrage universel et direct", Revue du Marché Comun, núm. 335, mars, 1990, págs. 216 a 218. R. SCARPA: "Considerazioni in ordine a una procedura uniforme per I'elezione dei deputati all'Assemblea del Parlamento Europeon, Affari Sociali Internazionali, núm. 2, 1985, págs. 61 a 67.

En España cabe destacar: F. SANTAOLALlA LóPEZ: Sistema electoral del Parlamento Europeo, Fundación Juan March, serie universitaria, 234, Madrid, 1986, "Reflexiones sobre la normativa española para las elecciones del Parlamento Europeo", Revista de las Cortes Generales, núm. 9, 1986, págs. 293 a 308 y Elección en España del Parlamento Europeo, Madrid, Civitas, 1987, págs. 63 a 72. F. ALDECOA LuzurRaga y A. MuÑoz Álvarez: "Hacia una ley electoral uniforme para las elecciones al Parlamento Europeo: Problemas que suscita", Revista de Instituciones Europeas, vol. 13, núm. 3, septiembre-diciembre, 1986, págs. 631 a 652 . J. ELIZALDE: «EI régimen electoral del Parlamento Europeo: ¿Quiebra en la primacía del Derecho Comunitario?", Revista de Instituciones Europeas, vol. 16, núm. 3, septiembrediciembre, 1989, págs. 809 a 836. E.A. AlCUBILLA: «Elecciones al Parlamento Eu- 
El 10 de octubre de 1991, no obstante, el Parlamento Europeo adoptó una Resolución sobre el procedimiento electoral uniforme en la que estableció que, en lo referente al derecho de sufragio, todo nacional de un Estado miembro de la Comunidad Europea, si en la fecha del escrutinio, tuviese la edad de 18 años cumplidos, puede ser elector y elegible al Parlamento Europeo en el Estado miembros donde tenga su domicilio principal durante al menos un año, respetándose las disposiciones específicas en vigor en los Estados miembros que confieran a otros nacionales residentes el derecho de sufragio y comprometiéndose los Estados miembros a cooperar para evitar el doble ejercicio del voto ${ }^{24}$.

ropeo", en Revista de Derecho Político, núms. 27-28, 1988, págs. 319 a 352. A. Allué Buiza: El Parlamento Europeo. Poder y Democracia en las Comunidades Europeas. Valladolid, Universidad de Valladolid, 1990, págs. 56 a 68. A. EMBID IRUJo: "El parlamento Europeo», en Tratado de Derecho Comunitario Europeo, vol. I, dir. E. García de Enterría, J.D. González Campos y S. Muñoz Machado, Madrid, Ed. Civitas, 1986, págs. 63 a 91. P. PEÑA: "Las transformaciones del Parlamento Europeo", en Revista de las Cortes Generales, núm. 9, 1986, págs. 64 y 65.

24 Documento de Sesión, Parlamento Europeo, Comunidades Europeas, A3-152/91, de 10 de octubre de 1991, pág. 26.

Disposiciones similares se contenían en el Informe Provisional DE GUCHT de la Comisión institucional sobre las orientaciones del Parlamento Europeo relativas al proyecto de procedimiento uniforme para los miembros del Parlamento Europeo si bien, en el dictamen adjunto al mismo, el Informe SPERONI de la Comisión jurídica y de derechos de los ciudadanos propugnaba que los ciudadanos pudiesen ejercer el derecho de sufragio activo y pasivo en el Estado "tras un período de residencia de, al menos, cinco años" (Documentos de Sesión, Parlamento Europeo, Comunidades Europeas, A3-0152/91, de 29 de mayo de 1991) y, con anterioridad, en la Propuesta de resolución provisional de la Comisión Institucional el informante De Gucht proponía que el proyecto de procedimiento electoral uniforme estableciese la posibilidad de derogar el derecho de sufragio a los ciudadanos comunitarios en los paises de residencia uen los países que tuviesen una inmigración de ciudadanos de la CEE superior al 20 por 100 del cuerpo electoral de ese Estado miembro" (Proposition de resolution intérimaire sur "les orientations du Parlement européen relatives au projet de procédure électorale uniforme pour les membres du Parlement européen", Rapporteur: M. KAREL DE GUCHT, Parlamento Europeo, 140.107, de 21 de marzo de 1990).

Sobre el impulso del Parlamento Europeo en el reconocimiento de este derecho y para la elaboración del procedimiento electoral uniforme véase la Resolución de 12 de diciembre de 1990 sobre los fundamentos constitucionales de la Unión Europea (op.cit.) y el Diario Oficial de las Comunidades Europeas, Debates del Parlamento Europeo, núm. 2-374 anexo, de 15 de febrero de 1989, págs. 158 y 159. 


\section{EL DERECHO DE SUFRAGIO DE LOS EXTRANJEROS EN LOS ESTADOS MIEMBROS DE LA COMUNIDAD EUROPEA}

La situación del derecho de sufragio de los extranjeros en las elecciones municipales y europeas de los once Estados miembros -el supuesto español lo expondremos a posteriori- exige diferenciar entre:

a) Países que conceden el derecho de sufragio a todos los extranjeros en las elecciones municipales:

- En Dinamarca la Ley de 3 de agosto de 1989 reconoce derecho de sufragio activo y pasivo a quien teniendo 18 años y residencia permanente en el municipio, sea de nacionalidad danesa o haya residido permanentemente en Dinamarca durante los tres años anteriores al día de la elección ${ }^{25}$.

- En los Países Bajos el art. 130 de la Ley Fundamental del Reino fue revisado el 19 de enero de 1983 y establece que "la ley podrá conceder el derecho de elegir a los componentes del Ayuntamiento y el de formar parte del mismo a los vecinos que, no siendo holandeses, reúnan al menos los requisitos exigibles a los residentes que al mismo tiempo sean holandeses" 26 -el antiguo texto exigía la nacionalidad holandesa para ejercer el derecho de voto o poder ser elegido concejal-.

La modificación de la Ley Municipal y Ley de 28 de septiembre de 1989 conceden la condición de elector a los habitantes de la Comunidad que el día de la elección tengan 18 años y, si no son holandeses, que hayan residido en Holanda durante un período ininterrumpido de, al menos, cinco años y que tengan permiso de residencia de acuerdo con los arts. 9

25 La ley danesa de 18 de mayo de 1977 ya reconocía este derecho a los extranjeros procedentes de la Unión Nórdica (Finlandia, Islandia, Noruega y Suecia) pero fue ampliado por la Ley de 30 de marzo de 1981.

La Constitución danesa de 5 de junio de 1953 se limita a reservar el derecho de sufragio para las elecciones del Folketing a utoda persona de nacionalidad danesa que tenga domicilio fijo en el Reino..." (arts. 29 y 30 ).

${ }_{26}$ Boletín de Legislación Extranjera, Cortes Generales, Traduc. M. Daranas Peláez, núm. 25, 1983, pág. 981.

La Ley Fundamental del Reino de los Países Bajos reserva a los holandeses el derecho a uelegir a los miembros de sus órganos de representación general, así como a ser elegidos miembros de los mismos" (art. 4), "los miembros de la Segunda Cámara" (art. 54), a "ser miembro de los Estados Generales" (art. 56) y a elegir "los componentes de los Estados Provinciales" (art. 129). 
y 10 de la ley sobre extranjeros o en virtud de los Tratados constitutivos de la CEE o el Tratado de fundación del Benelux, pero excluye a las personas que estén al servicio de otro Estado del cual son nacionales y a sus familiares (art. B.3 y 4). La Ley holandesa de 29 de junio de 1851, reformada por la Ley de 13 de diciembre de 1989, prevé los mismos requisitos para ser miembro de un Consejo Municipal que para ser elector.

- En Irlanda la Electoral Act de 1973 reconoce el derecho de sufragio activo a todos los extranjeros que residan habitualmente durante, al menos, seis meses y la Electoral Act de 1974 extiende el derecho a la condición de elegible en el municipio de domicilio si se cumplen los requisitos exigidos para votar.

b) Países que conceden el derecho de sufragio a algunas categorias de extranjeros en las elecciones municipales:

En el Reino Unido los arts. 1,2 y 12 de la «Representation of the people Act" de 1983 otorga derecho de sufragio activo y pasivo a los ciudadanos de la Commonwealth y de la República de Irlanda tras un período de residencia suficientemente largo, a juicio del juez, y si están inscritos en el censo electoral.

En Portugal el art. 15 de la Constitución establece que los extranjeros residentes en Portugal gozarán de los derechos del ciudadano portugués exceptuándose los derechos políticos y el ejercicio de las funciones públicas que no tengan un carácter meramente técnico aunque "se podrán otorgar a los ciudadanos de países de lengua portuguesa, en virtud de convenio internacional y a condición de reciprocidad, derechos no conferidos a los extranjeros, salvo el acceso a la titularidad de los órganos de soberanía y de gobierno propio de las regiones autónomas» y la "ley podrá otorgar a los extranjeros residentes en el país, en condiciones de reciprocidad, capacidad electoral para la elección de los titulares de órganos de las autoridades locales" ${ }^{27}$.

La Convención de 7 de septiembre de 1971 relativa a la igualdad de derechos y obligaciones entre brasileños y portugueses permite el reconocimiento del derecho de sufragio activo de los brasileños en Portugal.

27 El último entrecomillado constituye un apartado nuevo añadido por la reforma de 1989 (Boletín de Legislación Extranjera, Cortes Generales, Traduc. M. Daranas Peláez, núms. 96-97, septiembre-octubre, 1989).

Los arts. 49 y 50 de la Constitución portuguesa reservan a los ciudadanos portugueses el derecho de sufragio y de acceso a los cargos públicos. 
c) Países que reconocen a los nacionales de Estados miembros de la Comunidad Europea el derecho de sufragio activo en las elecciones europeas:

- En Bélgica la Ley de 27 de febrero de 1984, relativa a la elección del Parlamento Europeo, modificó la Ley de 16 de noviembre de 1978 y estableció que pueden adquirir la cualidad de elector para el Parlamento Europeo los nacionales de otros Estados miembros de la Comunidad Europea con 18 años cumplidos y tres años de residencia ininterrumpida en Bélgica (arts. 1 y 3) ${ }^{28}$.

- En Irlanda la European Assembly Elections Act de 1984 atribuye a los ciudadanos de otros Estados de la CEE residentes en Irlanda el derecho de votar a los candidatos irlandeses ${ }^{29}$.

- En los Países Bajos, en virtud de la Ley de 13 de diciembre de 1978 que regula la elección de los miembros del Parlamento Europeo, son electores aquellos que, no siendo holandeses, tengan la ciudadanía de otro Estado miembro de la Comunidad Europea siempre que el día de la presentación de las candidaturas tengan la efectiva residencia en los Países Bajos y en la fecha de la votación cumplan 18 años.

- En el Reino Unido la European Assembly Elections Act de 1981 atribuye derecho de voto a los ciudadanos británicos e irlandeses residentes en el Reino Unido y mayores de 18 años ${ }^{30}$.

d) Países que reconocen a los nacionales de Estados miembros de la Comunidad Europea el derecho de sufragio pasivo en las elecciones europeas:

28 Moniteur belge, 6 de marzo de 1984, págs. 2914 y 2915. La Constitución belga, no obstante, establece en su art. 4 que "La calidad de belga se adquiere, conserva y pierde con arreglo a las reglas establecidas por la ley civil. La presente Constitución y las demás leyes relativas a las leyes políticas determinarán cuáles son, aparte de esta calidad, las condiciones necesarias para ejercer esos derechos" y en su art. 5 que la unaturalización será otorgada por el Poder Legislativo. Sólo la naturalización plena asimilará al extranjero con el belga para el ejercicio de los derechos políticos" (M. DARANAS: Las Constituciones Europeas, tomo I, Madrid, Editora Nacional, 1979, pág. 361).

29 Legislación electoral para las elecciones europeas, Colección Ciencia y Documentación, Parlamento Europeo, Dirección General de Estudios, núm. 13, 1989, Luxemburgo, pág. 25.

30 Halsbury's Statutes of England, third edition, vol. 48, London, 1979. 
- En Italia la Ley de 9 de abril de 1984, núm. 61, que modifica la ley de 24 de enero de 1979, núm. 18, atribuye el derecho de sufragio pasivo a los ciudadanos de los doce países miembros de la Comunidad Europea ${ }^{31}$.

e) Países que niegan a los extranjeros el derecho de sufragio:

Vistos los casos de aquellos países comunitarios que reconocen el derecho de sufragio activo o pasivo en elecciones municipales o europeas -bien entendido que, a sensu contrario, quedan excluidas en estos mismos las restantes posibilidades del derecho de sufragio para los extranjeros podemos constatar que los restantes países comunitarios excluyen totalmente del derecho a sufragio a los extranjeros.

- En Luxemburgo la Constitución establece en su art. 9 que «la cualidad de luxemburgués se adquiere, se conserva y se pierde con arreglo a las normas fijadas por la ley civil. La presente Constitución y las demás leyes relativas a los derechos políticos determinarán cuáles son, además de dicha cualidad, las condiciones necesarias para el ejercicio de esos derechos" y en el art. 52 que, para ser elector o elegible de la Cámara de Diputados, será necesario "ser luxemburgués o luxemburguesa" - precepto de interés por cuanto el art. 107 prescribe que habrá «en cada municipio un Ayuntamiento elegido directamente por los habitantes que reúnan, además de los requisitos del art. 52 de la Constitución, las condiciones de residencia que la ley determine»- ${ }^{32}$.

- En Grecia la Constitución prevé en su art. 4.4 que «sólo los ciudadanos griegos serán elegibles para servicios públicos, excepto lo que prevean leyes especiales", y en sus arts. 51 y 55 reserva la cualidad de elector y elegible, respectivamente, en la elección del Parlamento, a los ciudadanos griegos ${ }^{33}$.

31 Gazzetta Ufficiale de la República Italiana, núm. 101, de 11 de abril de 1984, pág. 3062.

La Constitución italiana, no obstante, establece en su art. 48 que "son electores todos los ciudadanos, hombres y mujeres, que hayan alcanzado la mayoría de edad" y en su art. 51 que "todos los ciudadanos de uno y otro sexo podrán desempeñar cargos públicos y puestos electivos en condiciones de igualdad, según los requisitos establecidos por la ley" y la "Ley podrá, para la admisión a los cargos públicos y a los puestos electivos, equiparar a los ciudadanos a quienes no pertenezcan a la República".

32 Boletín de Legislación Extranjera, Cortes Generales, Traduc. M. Daranas Peláez, núms. 92-93, 1989.

33 Constitution of Greece, House of Parliament, Athéns, 1979. 
- En Francia el art. 3 de la Constitución establece que "son electores, en las condiciones establecidas por la ley, todos los nacionales franceses...» 34 .

- En Alemania el art. 20.2 de la Ley Fundamental de Bonn establece que todo el poder estatal emana del "pueblo" quien lo ejercerá en las "elecciones y votaciones" y el art. 28.1 dispone que en los Länder y municipios «el pueblo tendrá una representación que emane de elecciones por sufragio universal...".

Las Constituciones de Bade-Würtemberg (art. 26.1), Baviera (art. 4), Berlín (art. 2.1), Hesse (art. 73.1), Renania-Palatinado (art. 50.1) y Sarre (art. 66.1) reservan a los nacionales alemanes el derecho de sufragio activo $y$ pasivo en todas las elecciones, pero las Constituciones de Brême (artículo 55.1), Hamburgo (art. 3.2), Baja Sajonia (art. 2.1), Renania del Norte-Palatinado (art.2) y Schleswig-Holstein (art. 2.1) únicamente se refieren, al igual que la Ley Fundamental, al "pueblo» ${ }^{35}$.

34 Boletín de Legislación Extranjera, Cortes Generales, Traduc. M. Gonzalo y N. Pérez-Serrano, núm. 5, 1982.

Sobre la polémica de la aplicación de los Tratados de Maastricht en Francia véase la intervención del eurodiputado Guermeur en el Diario Oficial de las Comunidades Europeas, Debates del Parlamento Europeo, núm. 2-376, de 14 de marzo de 1989, pág. 83 y téngase en cuenta que el art. 24 de la Constitución francesa establece que "el Senado se elige por sufragio indirecto" y "garantiza la representación de las corporaciones territoriales de la República».

El Gobierno francés ha iniciado el 22 de abril de 1992 el proceso de reforma constitucional, previa a la ratificación del Tratado, proponiendo la inclusión de un nuevo artículo que concedería a los ciudadanos de la Comunidad Europea residentes en Francia la posibilidad de votar y ser elegido en las elecciones municipales pero no el ejercicio de las funciones de alcalde o de teniente de alcalde.

${ }^{35}$ Le droit de vote des etrangers aux elections locales dans les pays européens, Senat français, Service des affaires européenes, Paris, 6 de novembre de 1989.

En febrero de 1989 la Dieta de Hamburgo acordó que todos los extranjeros residentes en Hamburgo durante, al menos, ocho años tuviesen derecho a votar los Consejos de distrito. El 21 de febrero de 1989 la Dieta de Schleswig-Holstein otorgó el derecho de voto en las elecciones municipales de 1990 a los nacionales de los Estados que reconocen este derecho a los alemanes (Suiza, Dinamarca, Noruega, Holanda, Irlanda y Suecia), siempre que hubieran residido durante más de cinco años, y previó su extensión a todos los extranjeros en 1994. Estas previsiones, no obstante, han sido anuladas $y$ el Tribunal Constitucional Alemán ha negado el derecho al voto a los extranjeros (BVerfGE, Bd.6, S.84, 91; Bd.8, S.51, 68f; Bd.14, S.121, 132; Bd.20, S.56, 98f., 113; Bd.51, S.222, 234, en W. Schreiber: Handbuch des Wahlrechts zum Deutschen Bundestag, tercera edición, 1986). 


\section{EL DERECHO DE SUFRAGIO \\ DE LOS EXTRANJEROS EN ESPAÑA}

\section{A. La reserva constitucional del art. 13 en favor de los españoles y su excepción: el consenso constituyente}

El Capítulo Primero del Título I del texto constitucional hace referencia al estatuto jurídico de los extranjeros en España, estableciendo el artículo 13.1 que los «extranjeros gozarán en España de las libertades públicas que garantiza el presente título en los términos que establezcan los tratados y la ley». El reconocimiento del derecho de sufragio a los extranjeros, no obstante, encuentra su reflejo en el art. 13.1 de la Constitución en los siguientes términos:

"Solamente los españoles serán titulares de los derechos reconocidos en el art. 23, salvo lo que, atendiendo a criterios de reciprocidad, pueda establecerse por tratado o ley para el derecho de sufragio activo en las elecciones municipales".

Este precepto constitucional reserva a los españoles, salvo el derecho de sufragio activo en las elecciones municipales, la titularidad de los derechos reconocidos en el art. 23, es decir, "el derecho a participar en los asuntos públicos, directamente o por medio de representantes, libremente elegidos en elecciones periódicas por sufragio universal" y el "derecho a acceder en condiciones de igualdad a las funciones y cargos públicos, con los requisitos que señalen las leyes". El art. 13.1, en relación con el art. 23, excluye a los extranjeros de la titularidad del derecho de sufragio activo $y$ pasivo en España salvo, en determinadas circunstancias, el derecho de sufragio activo en las elecciones municipales.

A continuación penetraremes en el estudio de la tramitación parlamentaria constituyente de estos preceptos a fin de aproximarnos a la voluntad constituyente que los inspira, máxime cuando la ratificación del Tratado de Maastricht, según polémica abierta entre la doctrina, podría exigir una reforma de los mismos.

El Anteproyecto de Constitución establecía en los apartados 1 y 2 de su art. 12:

"1. La condición jurídica del extranjero se regulará por la ley y por los tratados, atendiendo siempre el criterio de efectiva reciprocidad. Solamente los españoles serán titulares de derechos políticos. 
2. Los extranjeros residentes en España gozarán de las libertades públicas del presente título, en los términos que la ley establezca" ${ }^{36}$.

El art. 23 del Anteproyecto, por su parte, establecía:

11. Todos los ciudadanos mayores de edad tienen el derecho a participar en los asuntos públicos, directamente o por medio de representantes, libremente elegidos en elecciones periódicas por sufragio universal.

2. Asimismo tienen derecho a acceder en condiciones de igualdad a las funciones y cargos públicos con los requisitos que señalen las leyes" ${ }^{37}$.

Al art. 12 del Anteproyecto el Grupo Parlamentario Socialista del Congreso presentó un voto particular - al cual se adheriría Letamendía Belzunce (Grupo Parlamentario Mixto) en sus enmiendas ${ }^{38}$ - proponiendo la supresión del término "efectiva" y la frase "solamente los españoles serán titulares de derechos políticos" ${ }^{39}$ y una enmienda que proponía la sustitución de estos dos apartados por un nuevo apartado primero que se limitaba a establecer que "la condición jurídica del extranjero se regulará por la Ley y por los tratados" 40 -en el mismo sentido una enmienda del Grupo Parlamentario Socialistes de Catalunya ${ }^{41}$-. Solé Barberá (Grupo Parlamentario Comunista) enmendaría el texto proponiendo, también, la supresión del término "efectiva", por entender que el término "reciprocidad" constituye un concepto jurídico cuya efectividad debe suponerse en un Estado de Derecho, y de la frase "solamente los españoles serán titulares de derechos políticos", considerando que los derechos políticos pueden extenderse a ciudadanos extranjeros en la participación de la vida política municipal como ocurre, por ejemplo, en Suecia ${ }^{42}$. También este Grupo propondría la adición en el apartado segundo de la tendencia

36 Boletín Oficial de las Cortes, núm. 44, 5 enero 1978, pág. 671, en Constitución Española, Trabajos Parlamentarios, Cortes Generales, 1980, pág. 9.

37 Boletín Oficial de las Cortes, núm. 44, 5 enero 1978, pág. 673, en Constitución Española, Trabajos Parlamentarios, Cortes Generales, 1980, pág. 11.

38 Constitución Española, Trabajos Parlamentarios, Cortes Generales, 1980, pág. 166.

39 Boletín Oficial de las Cortes, núm. 44, 5 de enero 1978, pág. 713, en Constitución Española, Trabajos Parlamentarios, Cortes Generales, 1980, pág. 51.

40 Constitución Española, Trabajos Parlamentarios, Cortes Generales, 1980, pág. 275.

41 Constitución Española, Trabajos Parlamentarios, Cortes Generales, 1980, pág. 245.

42 Constitución Española, Trabajos Parlamentarios, Cortes Generales, 1980, pág. 419. 
"hacia su más amplia equiparación con los españoles" ${ }^{43}$. Carro Martínez (Alianza Popular), por último, propuso una enmienda de supresión del párrafo 2 por considerarlo reiterativo del primero ${ }^{44}$.

El Informe de la Ponencia a las enmiendas al Anteproyecto de Constitución modificó el art. 12.1 - "La condición jurídica del extranjero se regulará por ley y por los tratados. Solamente los españoles serán titulares de derechos políticos"-, manteniendo el apartado segundo, y dio su configuración actual al art. 23 de la Constitución ${ }^{45}$. El Dictamen de la Comisión de Asuntos Constitucionales y Libertades Públicas del Congreso de los Diputados reafirmaría el texto si bien suprimió el término "residente en España" ${ }^{46}$-que sería el texto del Proyecto de Constitución aprobado por el Pleno del Congreso ${ }^{47}$ - y el Grupo Parlamentario Socialista mantuvo su enmienda de supresión de la referencia a que "solamente los españoles serán titulares de derechos políticos" ${ }^{48}$.

En el Senado el Texto del Proyecto de Constitución aprobado por el Congreso fue objeto de las siguientes enmiendas: Progresistas y Socialistas Independientes propusieron la sustitución de los dos apartados del artículo 12 por «los extranjeros gozarán en España de las libertades públicas que garantiza el presente Título, en los términos que establezca la ley reguladora de su condición jurídica y los tratados" y denunciaron la "gravedad" de la exclusión constitucionalizada de los extranjeros en el ejercicio de cualesquiera derechos políticos en un proceso de integración supranacional ${ }^{49}$. Landáburu González (Grupo Mixto) propuso que sólo los españoles fueran utitulares de los derechos políticos establecidos en la presente Constitución y las leyes orgánicas" considerando obvio que sólo los nacionales son titulares de derechos políticos y que los extranjeros pueden ejercitar sus derechos políticos en España dentro de sus Embajadas y Consulados ${ }^{50}$. La Agrupación Independiente propuso que los extran-

43 Véase cita anterior.

44 Constitución Española, Trabajos Parlamentarios, Cortes Generales, 1980,

pág. 123.

45 Boletín Oficial de las Cortes, núm. 82, 17 abril 1978, págs. 1528 y 1529, en Constitución Española, Trabajos Parlamentarios, Cortes Generales, 1980, páginas 512 y 513.

46. Boletín Oficial de las Cortes, núm. 121, 1 julio 1978, pág. 2593, en Constitución Española, Trabajos Parlamentarios, Cortes Generales, pág. 1805.

47 Boletín Oficial de las Cortes, núm. 135, 24 julio 1978, pág. 2947, en Constitución Española, Trabajos Parlamentarios, Cortes Generales, pág. 2577.

48 Boletín Oficial de las Cortes, núm. 121, 1 julio 1978, pág. 2637, en Constitución Española, Trabajos Parlamentarios, Cortes Generales, pág. 1849.

49 Constitución Española, Trabajos Parlamentarios, Cortes Generales, 1980, pág. 2675.

50 Constitución Española, Trabajos Parlamentarios, Cortes Generales, 1980, pág. 2844. 
jeros gozaran de las libertades públicas del Título I «salvo limitación expresa legalmente establecida" pero reservando la titularidad de los derechos políticos a los españoles a fin de no dar un sentido demasiado restrictivo que pudiera interpretarse privando a los extranjeros de derechos tales como la reunión o asociación y ajustándolo mejor a los criterios del Pacto Internacional de Derechos Civiles y Políticos (art. 2.1) y al Convenio Europeo de Derechos Humanos (art. 1) ${ }^{51}$. Socialistas del Senado, por último, propuso suprimir que sólo los españoles fueran titulares de derechos politicos por «en ningún caso podrán participar como electores y elegibles en las elecciones al Congreso de los Diputados y al Senado" a fin de adecuar nuestra Constitución a las recomendaciones internacionales y posibilitar la participación de los extranjeros en las elecciones municipales y permitir exigir igual trato a otros paises respecto a los emigrantes españoles ${ }^{52}$.

El art. 13.1 del Dictamen de la Comisión de Constitución del Senado introdujo una novedosa redacción - «Los extranjeros gozarán en España de las libertades públicas que garantiza el presente Título en los términos que establezcan los tratados y la ley reguladora de su condición jurídica» ${ }^{53}$-, suprimió la reserva de la titularidad de los derechos políticos en favor de los españoles lo que constituyó una modificación propuesta por el Pleno del Senado al texto del proyecto de Constitución aprobado por el Congreso de los Diputados ${ }^{54}$.

La redacción definitiva del art. 13.2 de la Constitución surgiría del Dictamen de la Comisión Mixta Congreso-Senado sobre el Proyecto de Constitución ${ }^{55}$.

La tramitación parlamentaria del art. 13 nos muestra cómo la reserva de los derechos políticos en favor de los españoles fue una constante en el Congreso de los Diputados, desapareció en el Senado y fue parcialmente asumida por la Comisión Mixta Congreso-Senado. Del estudio de las enmiendas y votos particulares formulados al Proyecto de Constitución $y$ de las intervenciones efectuadas podemos deducir dos posiciones

51 Constitución Española, Trabajos Parlamentarios, Cortes Generales, 1980, pág. 2946.

52 Constitución Española, Trabajos Parlamentarios, Cortes Generales, 1980, pág. 2950.

53 Boletín Oficial de las Cortes, núm. 157, 6 octubre 1978, pág. 3417, en Constitución Española, Trabajos Parlamentarios, Cortes Generales, 1980, página 4197.

54 Boletín Oficial de las Cortes, núm. 161, 13 octubre 1978, págs. 3560 y 3561, en Constitución Española, Trabajos Parlamentarios, Cortes Generales, 1980, págs. 4846 y 4847.

56 Boletín Oficial de las Cortes, núm. 170, 28 octubre 1978, pág. 3703, en Constitución Española, Trabajos Parlamentarios, Cortes Generales, 1980, pág. 4871. 
netamente diferenciadas que encontraría la síntesis en la definitiva redacción del art. 13.2:

a) La exclusión total de los extranjeros en el ejercicio del derecho de sufragio ${ }^{56}$ en España defendida, básicamente, por la Unión de Centro Democrático y Alianza Popular con los siguientes argumentos:

- La vinculación del derecho de sufragio al estatuto de ciudadano o nacional -como diría Fraga Iribarne, "...si el Estado nacional tiene un sentido es el de reservar la ciudadanía, el status activae civitatis, a sus propios ciudadanos, a sus propios nacionales..." ${ }^{57}$.

- Los peligros acechantes de la inmigración emergente - «...España en este momento, por vía de inmigración, por el mismo nivel de vida, por la vía de numerosos residentes políticos y otros que pasan largas temporadas en España, podría encontrarse con problemas de una cierta importancia.... ${ }^{58}$.

- La transferencia de competencias a entidades supranacionales prevista en el Texto -Pérez-Llorca señalará que "...los posibles inconvenientes que se podrían derivar de la existencia de este párrafo en relación con nuestra plena adhesión a una serie de instituciones europeas...está solucionado por la Constitución en otros preceptos que prevén explícitamente la transferencia de competencias a instituciones europeas..." 59 .

56 Si bien el texto del Proyecto constitucional hacia referencia a la reserva de los «derechos políticos» - los senadores Sánchez Agesta y Villar Arregui se encargarian de poner de manifiesto la indeterminación del concepto y la confusión que podía originar (Diario de Sesiones del Senado, Comisión de Constitución, núm. 42, 23 agosto 1978, págs. 1776 y 1777 en Constitución Española, Trabajos Parlamentarios, Cortes Generales, 1980, págs. 3182 y 3183)-, pronto el debate quedaría reducido a la exclusión de los extranjeros en el ejercicio del derecho de sufragio pues, como señaló Alzaga, "...el primer párrafo del art. 12, cuando se refiere a los derechos políticos básicamente, y sin perjuicio de otros, está pensando en el derecho de sufragio como instrumento, según se concibe en el art. 23, de participación y de elección de los representantes....) (Diario de Sesiones del Congreso de los Diputados, Comisión de Asuntos Constitucionales y Libertades Públicas, núm. 68, 17 de mayo 1978, pág. 2415, en Constitución Española, Trabajos Parlamentarios, Cortes Generales, 1980, pág. 957).

57 Diario de Sesiones del Congreso de los Diputados, Comisión de Asuntos Constitucionales y Libertades Públicas, núm. 68, 17 mayo 1978, pág. 2416, en Constitución Española, Trabajos Parlamentarios, Cortes Generales, 1980, pág. 958.

58 Véase nota anterior.

59 Diario de Sesiones del Congreso de los Diputados, Comisión de Asuntos Constitucionales y Libertades Públicas, núm. 68, 17 mayo 1978, pág. 2422, en Constitución Española, Trabajos Parlamentarios, Cortes Generales, 1980, pág. 964. 
- La vinculación del derecho de sufragio a los deberos públicos derivados de la nacionalidad -Alzaga apuntará que "...el derecho político tiene siempre, como otro lado de la moneda, el deber político. No hay auténtico derecho político en una sociedad participativa moderna sin el deber de los ciudadanos a asumir la vida política...Porque vamos a una democracia gobernante, a una auténtica democracia participativa, los deberes que va a implicar para la ciudadanía sólo tenemos autoridad moral en esta Cámara para imponérselos a los españoles..."- ${ }^{60}$.

b) El reconocimiento parcial del derecho de sufragio de los extranjeros en España propuesto, fundamentalmente, por el PSOE y el PCE, por las siguientes razones ${ }^{61}$ :

- La progresiva quiebra de la vinculación entre la nacionalidad y la titularidad de los derechos políticos derivada, como diría Zapatero, "de la internacionalización de la vida social y política...desde una perspectiva de la integración de España en organismos supranacionales» ${ }^{62}$. Peces Barba, en una intervención profética, rechazó la tesis clásica de la titularidad de los derechos políticos y advirtió que la reserva en favor de los españoles iba "...a obligar dentro de pocos años a una reforma constitucional, y los socialistas no queremos ser responsables de esta reforma constitucional que, además si se aprueba el Título referente a la re-

60 Diario de Sesiones del Congreso de los Diputados, núm. 105, 6 julio 1978, pág. 3935, en Constitución Española, Trabajos Parlamentarios, Cortes Generales, 1980, pág. 2007.

61 Desde las posiciones que defendian parcialmente el derecho de sufragio de los extranjeros en España, no obstante, también existe un reconocimiento expreso de que la titularidad de los derechos contenidos en el art. 23 corresponde a los españoles. Véanse las intervenciones de Martín Toval (Diario de Sesiones del Congreso de los Diputados, Comisión de Asuntos Constitucionales y Libertades Públicas, núm. 68, 17 mayo 1978, pág. 2413, en Constitución Española, Trabajos Parlamentarios, Cortes Generales, 1980, pág. 955) y Zapatero - «...está claro que cuando aquí se habla de ciudadanos hay una restricción a los ciudadanos españoles $y$, por consiguiente, no se atribuye este derecho a los extranjeros. Ciudadano es aquel que ha adquirido o tiene el status civitatis, bien por nacimiento o por adquisición, con lo cual si suprimimos el inciso solamente podrían ser electores y elegibles los ciudadanos españoles y nadie más, en virtud del juego del art. 23 del texto constitucional...)- (Diario de Sesiones de/ Congreso de los Diputados, núm. 105, 6 julio 1978, pág. 3928, en Constitución Española, Trabajos Parlamentarios, Cortes Generales, 1980, pág. 2000).

62 Diario de Sesiones del Congreso de los Diputados, Comisión de Asuntos Constitucionales y Libertades Públicas, núm. 68, 17 mayo 1978, pág. 2414, en Constitución Española, Trabajos Parlamentarios, Cortes Generales, 1980, pág. 956. 
forma de la Constitución, tendrán, en este Título de Derechos y Deberes Fundamentales, especiales dificultades..." ${ }^{63}$.

- La integración real de los extranjeros residentes en España en la vida social y política ${ }^{64}$.

- El Derecho Comparado y los Tratados Internacionales que introducen el reconocimiento del derecho de sufragio de los extranjeros $y$ que prohiben las restricciones de derechos políticos ${ }^{65}$.

\section{B. Desarrollo legislativo del art. 13.2 de la Constitución}

El reconocimiento del derecho de sufragio activo de los extranjeros en España está contenido en la Ley Orgánica 7/1985, de $\uparrow$ de julio, de los Derechos y Libertades de los extranjeros en España, en la Ley 7/1985, de 2 de abril, reguladora de las Bases de Régimen Local y en la Ley Orgánica 5/1985, de 19 de junio, del Régimen Electoral General.

Los apartados 1 y 2 del art. 13 de la Constitución remiten a lo previsto en la Ley y los Tratados la configuración, en general, de las libertades públicas que garantiza el Título I de la Constitución y, en particular, el derecho de sufragio activo en las elecciones municipales, atendiendo a criterios de reciprocidad. El art. 1 de la Ley Orgánica 7/1985 considera extranjeros a quienes carecen de la nacionalidad española y el art. 5 establece que los extranjeros no podrán ser titulares de los derechos políticos de sufragio activo o pasivo ni acceder al desempeño de cargos públicos o que impliquen ejercicio de autoridad (apartado primero) pero se podrá recono-

63 Diario de Sesiones del Congreso de los Diputados, núm. 105, 6 julio 1978, pág. 3932, en Constitución Española, Trabajos Parlamentarios, Cortes Generales, 1980, pág. 2004.

También debe atribuirse el mérito "profético" a Villar Arregui (Diario de Sesiones del Senado, Comisión de Constitución, núm. 42, 23 agosto 1978, pág. 1777, en Constitución Española, Trabajos Parlamentarios, Cortes Generales, 1980, página 3183.

64 Véase la intervención de Solé Barberá en Diario de Sesiones del Congreso de los Diputados, Comisión de Asuntos Constitucionales y Libertades Públicas, núm. 68, 17 mayo 1978, pág. 2417, en Constitución Española, Trabajos Parlamentarios, Cortes Generales, 1980, pág. 959.

65 Véanse las intervenciones de Zapatero y Solé Barberá en Diario de Sesiones del Congreso de los Diputados, Comisión de Asuntos Constitucionales y Libertades Públicas, núm. 68, 17 mayo 1978, págs. 2415 y 2417, en Constitución Española, Trabajos Parlamentarios, Cortes Generales, 1980, págs. 957 y 959. 
cer el derecho de sufragio activo en las elecciones municipales a los extranjeros residentes, en los términos y con las condiciones que, atendiendo a criterios de reciprocidad, sean establecidos por tratado o por ley para los españoles residentes en los países de origen de aquéllos (apartado segundo).

La LO.7/1985 reproduce las previsiones constitucionales y, al mismo tiempo, introduce dos elementos configuradores del derecho referido:

- La «residencia» del extranjero en España,

- y la remisión a los tratados o leyes para que éstos determinen las condiciones de reciprocidad respecto a los españoles residentes en los países de origen de aquéllos.

El art. 18 de la Ley 7/1985, que regula los derechos y deberes de los vecinos, establece en su apartado segundo que los extranjeros domiciliados que sean mayores de edad tienen los derechos y deberes propios de los vecinos «salvo los de carácter político. No obstante tendrán derecho de sufragio activo en los términos que prevea la legislación electoral general aplicable a las elecciones locales" 66: Este precepto de la LrBRL aporta dos nuevos elementos configuradores del derecho constitucional referido:

- El domicilio en el municipio donde se pretenda ejercer el derecho de sufragio - a diferencia del español pero de conformidad con una interpretación conforme al sentido del derecho-.

- La mayoría de edad española.

El art. 176 de la Ley Orgánica 5/1985, modificado por la Ley Orgánica $8 / 1991$, de 13 de marzo ${ }^{67}$, establece que gozan del derecho de sufragio

66 Idéntica redacción la del art. 41.2 de la Ley 8/1987, de 15 de abril, Municipal y de Régimen Local de Cataluña (DOGC, núm. 832, de 27 de abril).

67 La redacción anterior del art. 176.1 decía: "Sin perjuicio de lo regulado en el Título I, Capítulo I, de esta Ley, gozan del derecho de sufragio activo en las elecciones municipales los residentes extranjeros en España cuyos respectivos países permitan el voto de los españoles en dichas elecciones, en los términos de un Tratadon.

El Proyecto de Ley Orgánica de Régimen Electoral General, en su art. 175.1, establecía: "Sin perjuicio de lo regulado en el Título I, Capítulo I, de esta Ley, gozan del derecho de sufragio activo en las elecciones municipales los residentes extranjeros en España, atendiendo en todo caso al principio de reciprocidad" (Boletín Oficial de las Cortes Generales, Congreso de los Diputados, núm. 120-I, 15 octubre 
activo en las elecciones municipales los residentes extranjeros en España cuyos respectivos países permitan el voto a los españoles en dichas elecciones, en los términos de un tratado o en el marco de la normativa comunitaria (apartado primero) y que el Gobierno comunicará a la Oficina del Censo Electoral la relación de Estados extranjeros cuyos nacionales, residentes en España, deban ser inscritos en el Censo (apartado segundo). De acuerdo con este precepto procede distinguir tres aspectos:

- La residencia del extranjero en España. Dicha situación se obtendrá y regirá por lo dispuesto en el art. 13 de la LO. 7/1985.

- La inscripción en el Censo Electoral. El art. 31.3 LOREG, modificado por la LO. 8/1991, de 13 de marzo ${ }^{68}$, establece que el Censo Electoral es único para toda clase de elecciones, sin perjuicio de su posible ampliación para las elecciones Municipales y del Parlamento Europeo a tenor de lo dispuestos en los arts. 176 y 210 de la presente Ley Orgánica.

- El título jurídico que da cobertura al derecho de sufragio activo de los extranjeros: un Tratado o la normativa comunitaria ${ }^{69}$. Tres son los posibles supuestos:

- La vigencia de este precepto respecto a terceros países ha dado lugar a los Acuerdos España-Suecia y España-Noruega, reconociendo el derecho a votar en las elecciones municipales a los nacionales suecos y

1984, en Ley Orgánica del Régimen Electoral General, Trabajos Parlamentarios, Cortes Generales, 1986, pág. 41).

En el Congreso de los Diputados, Vicens i Giralt (Grupo Mixto) propuso, sin éxito, intercalar después de "residentes extranjeros en España" las palabras "con siete años o más de residencia en el municipio" entendiendo que el derecho de sufragio activo de los extranjeros se justifica sólo cuando hay enraizamiento en el municipio (Ley Orgánica del Régimen Electoral General, Trabajos Parlamentarios, Cortes Generales, 1986, pág. 152).

En el Senado, el Grupo Parlamentario Socialista enmendaría el proyecto de ley añadiendo al final del apartado "en los términos de un tratado" a fin de determinar el título jurídico que ampara lo establecido en el precepto (Ley Orgánica del Régimen Electoral General, Trabajos Parlamentarios, Cortes Generales, 1986, página 870).

68 La redacción anterior del precepto decía: «El censo electoral es único para toda clase de elecciones, sin perjuicio de su posible ampliación para las elecciones municipales a tenor de lo dispuesto en el art. 13.2 de la Constitución".

69 La referencia a la "normativa comunitaria», incorporada por la LO. 8/1991, de 13 de marzo, encuentra su justificación en los antecedentes comunitarios que ya hemos expuesto en el apartado II de este trabajo. 
noruegos en España y a los españoles en Suecia y Noruega, realizados, ambos, en Madrid el 6 de febrero de $1990^{70}$.

- Con anterioridad al Tratado de Maastricht sólo dos países comunitarios suscribieron Acuerdos de reconocimiento del derecho a votar en elecciones municipales a los españoles en estos países y a sus nacionales en España: Paises Bajos (23 de febrero de 1989) y Dinamarca (13 de julio de 1989) ${ }^{71}$.

- Tras el Tratado de Maastricht, cualquier nacional de los Estados miembros de la Comunidad Europea podrá ejercer el derecho de sufragio activo en España de acuerdo con los requisitos establecidos en la legislación española.

El problema se suscita respecto al reconocimiento del derecho de

70 E.A. Alcubilla y M. Delgado-Iribarren García-Campero: Código Electoral, II, Actualización: abril 1991, Madrid, Publicaciones Abella, 1991, págs. 339 a 343.

Las condiciones para el ejercicio del derecho de voto en las elecciones municipales españolas por los ciudadanos suecos o noruegos serán: 1. Sólo podrán ejercer el derecho de sufragio activo en las elecciones municipales. 2. Deberán estar en posesión del permiso de residencia en España. 3. Deberán haber residido en España, legal e ininterrumpidamente, más de tres años. 4. Deberán estar domiciliados en el municipio en el que les corresponda votar y figurar inscritos en su Padrón municipal. 5. La inscripción en las listas electorales será requisito indispensable y se hará a instancia de parte en el Ayuntamiento en cuyo Padrón figure inscrito.

71 E.A. Alcubilla y M. Delgado-Iribarren Garcia-Campero: Código Electoral, II, Actualización: abril 1991, Madrid, Publicaciones Abella, 1991, págs. 333 a 341.

Las condiciones para el ejercicio del derecho de sufragio activo (en ambos paises se reconoce, también, el derecho de sufragio pasivo a los españoles residentes) en las elecciones municipales españolas para los ciudadanos neerlandeses y daneses serán:

1. Ser mayor de edad y no estar privado del derecho de sufragio (sólo en los Paises Bajos).

2. Residencia legal e ininterrumpida de más de tres años (en los Países Bajos se exigen cinco años de residencia a los españoles).

3. Posesión del permiso de residencia en España.

4. Inscripción en el Padrón Municipal de residencia habitual (Países Bajos) o en el que estén domiciliados y les corresponde votar (Dinamarca) -curiosamente los neerlandeses residentes en España no tienen una obligación de votar en su municipio de residencia expresada en el Acuerdo-.

5. La inscripción en las listas electorales de extranjeros residentes en España.

6. Se excluyen, en el supuesto neerlandés, aquellos que se encuentren al servicio de su Estado, sus cónyuges e hijos, cuando formen parte del hogar. 
sufragio pasivo en las elecciones municipales y el derecho de sufragio activo y pasivo en las elecciones europeas para los nacionales de Estados comunitarios residentes en España y la exigencia de reforma constitucional que, como veremos, el Tratado de Maastricht conlleva.

La Sentencia del Tribunal Constitucional 113/1991, de 20 de mayo, ha puesto de manifiesto la inexistencia de norma jurídica dictada por la Comunidad Europea que regule el derecho de sufragio activo o pasivo de los ciudadanos comunitarios y declara que "no pueden invocarse de forma genérica los principios comunitarios de libertad de circulación y establecimiento en cualquier lugar del territorio de los Estados miembros, ya que la falta del reconocimiento del derecho de sufragio pasivo en las elecciones locales en nada limita de forma directa esas libertades". No obstante, el Alto Tribunal aventura que la Comunidad y los Estados miembros pueden adoptar en el futuro medidas que, favoreciendo la participación política de todos los ciudadanos comunitarios, coadyuven a la plena vigencia de las libertades citadas y de otros objetivos comunitarios - como ocurrirá con la ratificación del Tratado de Maastricht- ${ }^{72}$.

\section{REFORMA CONSTITUCIONAL Y DERECHO DE SUFRAGIO DE LOS EXTRANJEROS}

\section{A. ¿Es necesaria la reforma constitucional? Tres posiciones doctrinales}

En los últimos días de enero del presente año saltó la polémica en torno a la necesidad de reformar el texto constitucional a fin de adaptarlo a los acuerdos de Maastricht en materia de reconocimiento del derecho de sufragio en las elecciones municipales españolas de los nacionales de Estados miembros de la Comunidad Europea. A pesar de su opinión contra-

72 STC 112/1991, de 20 de mayo, BJC 12 (1991), BOE de 19 de junio de 1991.

La mencionada Sentencia, de la que fue ponente el Magistrado De la Vega Benayas, desestimó el recurso de amparo electoral núm. 989/1991 interpuesto por la candidatura "Los Verdes de Andalucía" contra el acuerdo de la Junta Electoral de Motril de 29 de abril de proclamación de candidaturas por cuanto, en fecha 28 de abril, esa misma Junta Electoral había exigido la sustitución de D. Edward Emerentia Franz Vandoorne, de nacionalidad belga, candidato número uno de la lista "Los Verdes en Andalucía" en las elecciones municipales de $\mathbf{2 6}$ de mayo en la citada localidad de Motril. 
ria a la reforma y ante las serias dudas planteadas, el Gobierno, en Consejo de Ministros celebrado el 24 de abril, acordó, al amparo de lo dispuesto en el art. 95.2 de la Constitución, requerir al Tribunal Constitucional para que declare si existe o no contradicción entre la Constitución y el Tratado de Unión Europea que exija la previa revisión constitucional ${ }^{73}$.

Resumimos a continuación las tres posiciones doctrinales:

a) No necesidad de reforma: La vía del art. 93 de la Constitución.

La defensa de este planteamiento correspondió, inicialmente, al Gobierno que, con el soporte de un dictamen del Consejo de Estado elaborado en junio de 1991, negó la posibilidad de reforma y planteó una mera reforma del art. 176 de la Ley Orgánica de Régimen Electoral General que confiriese a los comunitarios residentes en España la condición de nacional español a los solos efectos de sufragio activo y pasivo en las elecciones municipales ${ }^{74}$.

73 El art. 78 LOTC establece: «1. El Gobierno o cualquiera de ambas Cámaras podrán requerir al Tribunal Constitucional para que se pronuncie sobre la existencia o inexistencia de contradicción entre la Constitución y las estipulaciones de un tratado internacional cuyo texto estuviera ya definitivamente fijado, pero al que no se hubiere presentado aún el consentimiento del Estado. 2. Recibido el requerimiento, el Tribunal Constitucional emplazará al solicitante y a los restantes órganos legitimados, según lo previsto en el apartado anterior, a fin de que, en el término de un mes, expresen su opinión fundada sobre la cuestión. Dentro del mes siguiente al transcurso. de este plazo y salvo lo dispuesto en el apartado siguiente, el Tribunal Constitucional emitirá su declaración que, de acuerdo con lo establecido en el art. 95 de la Constitución, tendrá carácter vinculante. 3. En cualquier momento podrá el Tribunal Constitucional solicitar de los órganos mencionados en el apartado anterior o de otras personas físicas o jurídicas u otros órganos del Estado o de las Comunidades Autónomas, cuantas aclaraciones, ampliaciones o precisiones estimen necesarias, alargando el plazo de un mes antes citado en el mismo tiempo que hubiese concedido para responder a sus consultas, que no podrá exceder de treinta días».

74 Virgilio Zapatero, Ministro para las Relaciones con las Cortes, afirmaría el 26 de enero de 1992: "....iniciar un proceso de reforma de la Constitución para resolver un problema de importancia relativa, como es el del sufragio pasivo de los comunitarios en nuestras elecciones municipales, me parece un exceso, si podemos resolver el problema por otros medios. $Y$ el problema tiene una solución menos costosa que la reforma constitucional, a través de un pequeño retoque de la Ley Orgánica de Régimen Electoral General, que confiere a los comunitarios residentes en España el estado de nacional español a los solos efectos del sufragio activo y pasivo en las elecciones municipales. Éste es un procedimiento más sencillo y de mayor economía legislativa..." (entrecomillado periodístico en El Pais, 27 enero 1992). En similar orientación Juan José Laborda, Presidente del Senado, en EI País, 28 de enero 1992. 
Con posterioridad la doctrina internacionalista ha señalado que resulta innecesaria la reforma constitucional por el juego que en el ordenamiento interno origina el art. 93 de la Constitución - según el cual mediante ley orgánica se podrá autorizar la celebración de tratados "por los que se atribuya a una organización o institución internacional el ejercicio de competencias derivadas de la Constitución"-. MANGAS MARTíN 75 - tras defender la superación del concepto de extranjería entre los ciudadanos miembros de la Comunidad Europea, señalar que los ámbitos régulados por los Tratados comunitarios y el derecho derivado se rigen exclusivamente por los principios de eficacia directa y primacía de toda norma comunitaria sobre cualquier norma interna (constitucional, ley estatal o autonómica...), recordar que numerosos preceptos constitucionales han quedado "comunicados" también para los ciudadanos de los otros Estados miembros (arts. 19, 24.2, 35, 39.1, 47, 50, 14...) desde el 1 de enero de 1986 y advertir que si triunfan las tesis reformistas habrá de procederse a reformar otros preceptos constitucionales (por ej. el art. 8D del Tratado reconoce el derecho de petición ante el Parlamento Europeo, sin limitaciones, lo que afectaría al art. 29.2 de la Constitución)- considera que el art. 93 "permite un doble juego al texto constitucional: éste sigue plenamente en vigor en los ámbitos que no se vean afectados por la acción comunitaria; pero si ésta tiene lugar, algunas normas constitucionales se verán condicionadas o simplemente serán apartadas o sustituidas por normas comunitarias". LÓPEZ GARRIDO, no obstante, estima que este precepto no resulta de aplicación por cuanto el Tratado de Maastricht no atribuye a órganos de la Comunidad Europea la competencia de decidir quién tiene derecho a sufragio pasivo sino que reconoce y fija ese derecho para todos los ciudadanos comunitarios ${ }^{76}$, y MARTínEZ CUADRADO entiende que "Maastricht avanza en dos elementos singulares de la soberanía de los Estados como son la condición de ciudadanos europeos con sus correspondientes derechos supranacionales y el más que simbólico ámbito de la moneda única" 77 . Frente a ello MANGAS MARTíN afirma que la atribución del ejercicio de competencias se refiere no sólo a la reducción

De Esteban ha considerado esta propuesta "de carácter surrealista y no necesita ningún comentario serio: se trataría, para salir del impasse constitucional, de incluir en la LOREG la concesión espasmódica, en cada elección municipal, de la nacionalidad española a los residentes comunitarios a los únicos efectos de que pudiesen presentarse como concejales..." (J. DE ESTEBAN: "Ciudadanía europea y reforma constitucional", El Mundo, 3 febrero 1992).

75 A. MANGAS MARTíN: "La reforma constitucional en España: Los Tratados internacionales (arts. 93 a 96 de la CE»), Ponencia presentada al Congreso La Reforma Constitucional en España, Logroño, 27 al 30 de abril de 1992.

76 El Pais, 26 enero 1992.

1992.

77 M. Martínez Cuadrado: "Maastricht y la Constitución”, El País, 7 febrero 
de competencias estatales en favor de las instituciones comunitarias sino, también, al establecimiento de nuevos derechos o a la extensión de ciertos derechos del nacional al ciudadano comunitario y, por ello, el Tratado de Unión Europea únicamente requeriría una mera adaptación de los arts. 2, 6, 176 y 177 LOREG.

Por último, apuntemos que SANTAOLALLA, con anterioridad a la polémica en curso, propuso la incorporación del derecho de sufragio activo y pasivo en las elecciones europeas de los nacionales de los Estados miembros que residiesen en España, basándose en que la reserva del artículo 13.2, en relación con el art. 23, sólo se refiere a la «participación en los asuntos públicos nacionales" y no a las instituciones supranacionales o comunitarias, en que "sería una toma de postura, si se quiere simbólica, en pro del fortalecimiento de la naturaleza supranacional de las elecciones del Parlamento Europeo" 78. DE ESTEBAN, tras el Tratado de Unión Europea, niega que este supuesto requiera una revisión constitucional, pues se trata de un plano que excede del marco institucional de cada Estado y de una materia que no es competencia de los Estados nacionales ${ }^{79}$.

b) Reforma necesaria pero limitada al art. 13.2 de la Constitución.

El art. 8B del Tratado de Unión Europea requeriría una reforma constitucional del art. 13.2 al entender de algunos ponentes constitucionales (PECES BARBA, PÉREZ LLORCA) y de sectores de la doctrina constitucionalista (LÓPEZ GARRIDO, JIMÉNEZ DE PARGA) ${ }^{80}$. En el mismo sentido PÉREZ ROYO considera que existe una contradicción entre la Constitución Española y el Tratado de Maastricht que debe ser resuelta mediante la supresión del adjetivo "activo" del art. 13.2 y su combinación con el art. 93 del texto constitucional. Se trata, al entender de este autor, de una ureforma por conexión o consecuencia", y no de una verdadera reforma constitucional -entendida ésta como «la revisión de alguna decisión política del constituyente que exija su sustitución por otra distintan-, que se debería realizar por el procedimiento general del art. 167 y de la forma umás económica" posible, es decir, por acuerdo de los tres quintos de ambas Cámaras y sin referendum posterior ${ }^{81}$.

c) La reforma inexcusable de los arts. 13.2 y 23 de la Constitución.

78 F. SANTAOLALLA LóPEZ: Reflexiones sobre la normativa..., págs. 296 a 298.

79 J. DE EsteBAN: "Ciudadanía europea y reforma constitucional", El Mundo, 3 febrero 1992.

80 El País, 26 enero 1992.

81 J. PÉREZ RoYo: «Un problema inexistente», El País, 13 febrero 1992. 
El art. 8 del Tratado de Unión Europea contempla el estatuto de la "ciudadania europea" cuyo contenido hace referencia, entre otras materias, a la participación política que se ejercerá en los términos del apartado $B$. El reconocimiento de derecho de sufragio pasivo en las elecciones municipales de los comunitarios residentes en España requiere, a juicio de DE ESTEBAN, de la reforma del art. $23.2-y$, por supuesto, del art. 13.2de la Constitución, por tratarse de una facultad únicamente reservada hasta la fecha a los españoles y, en consecuencia, de la puesta en funcionamiento del procedimiento especial de reforma constitucional previsto en el art. $168^{82}$ puesto que, abunda MARTÍNEZ CUADRADO, aunque se trate de una reforma parcial, tiene implicaciones que van más allá de una mera reforma técnica, pues afecta los derechos fundamentales definidos en el capítulo II, sección primera, del Título I (artículos conexos 13-23), y «la legitimación del tratado de Maastricht requiere alguna intervención tan cualificada como la del propio cuerpo electoral» ${ }^{83}$. Este último propone una reforma del art. 13, que evitase una redacción excluyente, y del art. 23, extendiendo, en un nuevo apartado, el derecho de sufragio a los ciudadanos europeos en consonancia con las previsiones del Tratado.

Frente a esta postura PÉREZ ROYO considera que el procedimiento de reforma constitucional previsto en el art. 168 constituye "la garantía última de la Constitución, pensada para casos extremos, en los que en cierta medida se viene abajo el edificio definido por la Constitución y la sociedad tiene que protagonizar un nuevo proceso constituyente. Por eso está diseñado como un procedimiento muy difícilmente transitable... Y justamente por eso también es por lo que tal artículo tiene que ser interpretado de manera restrictiva" ${ }^{84}$.

\section{B. La titularidad de derechos politicos. El art. 23 de la Constitución}

A la vista de las posiciones doctrinales expuestas acerca de la necesidad de reforma constitucional y del análisis de las previsiones normativas de nuestro ordenamiento, juzgamos de interés, en este punto, detenernos, previamente a ofrecer nuestra posición, en el estudio del elemento clave que planea sobre este trabajo: La titularidad de los derechos políti-

82 J. DE ESTEBAN: "Ciudadanía europea y reforma constitucional», El Mundo, 3 febrero 1992.

83 M. Martínez Cuadrado: "Maastricht y la Constitución", El Pais, 7 febrero 1992.

84 J. Pérez Royo: "Un problema inexistente", El País, 13 febrero 1992. 
cos, en general, y, en particular, la titularidad de los derechos reconocidos en el art. 23 de la Constitución.

La doctrina clásica ha atribuido la titularidad de los derechos políticos a los "ciudadanos", es decir, aquella categoría de los nacionales de un Estado que reúnen las condiciones legalmente previstas para ejercitar dichos derechos. Asi, los ricos debates constituyentes trajeron a colación, en intervención de Fraga Iribarne, las formulaciones de JELLINEK - "...tres niveles distintos de la libertad o derechos subjetivos: uno, el status o negatorio... Otro, el status de petición positiva...Y, finalmente, coronando esto, el status activae civitatis, el status de participación política, que es justamente donde aparecen la ciudadanía y los derechos políticos» ${ }^{85}-0$, en intervención de Alzaga refrendando esta doctrina, las de SANTAMARÍA DE PAREDES, SÁNCHEZ AGESTA, ROSSI o ROMANO ${ }^{86}$.

Si bien es cierto que es lugar común en la doctrina la vinculación de la titularidad del derecho de sufragio a la nacionalidad ${ }^{87}$; no es menos cierto que ha generado no poca confusión la identificación entre «nacionalidad" y "ciudadania". AGUIAR considera que no son conceptos "intercambiables", y siguiendo a PÉREZ-SERRANO, define a los ciudadanos como los unaturales del país que tienen la capacidad política legalmente reconocida para intervenir en la cosa pública» ${ }^{88}$. DE ESTEBAN, en el mis-

85 Diario de Sesiones del Congreso de los Diputados, Comisión de Asuntos Constitucionales y Libertades Públicas, núm. 68, 17 mayo 1978, págs. 2415 y 2416 , en Constitución Española, Trabajos Parlamentarios, Cortes Generales, 1980, páginas 957 y 958.

${ }_{86}$ Diario de Sesiones del Congreso de los Diputados, núm. 105, 6 julio 1978, pág. 3931, en Constitución Española, Trabajos Parlamentarios, Cortes Generales, 1980, pág. 2003.

Otras clasificaciones pueden encontrarse en: N. PÉrez-Serrano: Tratado de Derecho Político, Madrid, Civitas, 1976, págs. 599 a 601. A.E. Pérez LuÑo: Los Derechos Fundamentales, Madrid, Ed. Tecnos, 1986, pág. 181, G. Peces-Barba Martínez: "Derechos Fundamentales», en Diccionario del Sistema Político Español, dir. J.J. González Encinar, Madrid, Ed. Akal, 1984, págs. 214 a 216.

87 A. Torres del Moral: Principios de Derecho Constitucional, segunda edición, Madrid, Ed. Átomo, 1988, pág. 115. J.A. GonzÁlez CASANOva: Teoría del Estado $\checkmark$ Derecho Constitucional, Barcelona, Ed. Vicens-Vives, 1989, pág. 310. P. BISCARETTI DI RUFFIA: Derecho Constitucional, Madrid, Ed. Tecnos, 1987, pág. 309. G DE VERGOTTINI: Derecho Constitucional Comparado, Madrid, Ed. Espasa-Calpe, 1983, pág. 237. M. Martínez Sospedra: Las Instituciones del Gobierno constitucional, Valencia, Fund. San Pablo, CEU, 1988, pág. 116. P. PÉrez TremPS: Derecho Constitucional, VV.AA., vol. I, Valencia, Ed. Tírant lo Blanch, 1991, J.M. GIL-Robles y N. PÉrez-SERraNO: Diccionario de Términos Electorales y Parlamentarios, Madrid, Ed. Taurus, 1977, pág. 98.

88 L. AgUIAR dE LUQUE: "Art. 23. Derecho de Participación", en Comentarios a las Leyes Políticas, dir. Ó. Alzaga, tomo II, pág. 666. La cita de N. PÉrez-SerRano, op. cit., pág. 115. 
mo sentido, apunta que con la creación de los Estados nacionales tomó forma la condición de "nacional» como "vínculo jurídico que une a una persona con el Estado al que se halla sometido" que hay que diferenciar de la "ciudadanía" que es "un grado más elevado de la nacionalidad, puesto que sólo la alcanzan, en su proyección de titular de determinados derechos políticos, los nacionales mayores de edad, en plenitud de sus derechos" ${ }^{89}$. TORRES DEL MORAL prefiere el concepto de ciudadanía al de nacionalidad por cuanto "Estado y Nación ni se identifican ni son coextensivos" ${ }^{90} y$, paralelamente, PÉREZ-SERRANO critica la identificación clásica entre cuerpo electoral y Nación o Estado al entender que "fuera del electorado y dentro de la Nación quedan individuos y colectividades, fuerzas $y$ factores, idearios e intereses que no se manifiestan en las listas censales" "1. BISCARETTI, sin embargo, identifica nacionalidad y ciudadanía atribuyendo la segunda a las personas físicas y el uso de la primera para las personas jurídicas ${ }^{92}$.

"Con carácter general, pues - señala SÁNCHEZ FERRIZ ${ }^{93}$ - las libertades públicas, como los derechos fundamentales (salvo los políticos), se reconocen tanto a españoles como a extranjeros». Dentro de los derechos políticos, el art. 23 de la Constitución atribuye el derecho de sufragio activo y pasivo "a los ciudadanos" lo que debe traducirse, como la doctrina unánimemente señala ${ }^{94}$, en el reconocimiento de la titularidad del de-

89 J. DE ESTEBAN: "Ciudadanía europea y reforma constitucional», El Mundo, 3 febrero 1992.

90 A. TORRES del MORAL, op. cit., pág. 115.

91 N. Pérez-Serrano, op. cit., pág. 349.

92 P. BISCARETTI DI RUFFIA, op. cit., pág. 100.

93 R. SÁnchez FerRIz: Estudio sobre las libertades, Valencia, Ed. Tirant lo Blanch, 1989, pág. 177.

94 P. PÉrez Tremps, op. cit. 134. J.M. VALLÉS: "Derecho electoral», en Diccionario del Sistema Político Español, dir. J. J. González Encinar, Madrid, Ed. Akal, 1984, págs. 204 y 205. S. BASILE: "Los valores superiores, los principios fundamentales y los derechos y libertades públicas", en La Constitución Española de 1978. Estudio sistemático, dir. A. Predieri y E. García de Enterría, Madrid, Civitas, 1982 , pág. 311. A. FernÁnDEZ-MIRANDA Y CAMPOAMOR: "Art. 70. Causas de inelegibilidad e incompatibilidad y control judicial de las actas, electorales", en Comentarios a las Leyes Políticas, dir. Ó. Alzaga, tomo IX, págs. 241 y 242. E. SagarRA I Trias: Los derechos fundamentales y las libertades públicas de los extranjeros en España, Barcelona, Ed. Bosch, 1991, pág. 51. R.M. FerReR PeÑA: Los derechos de los extranjeros en España, Madrid, Ed. Tecnos, 1989, págs. 78 y 79. I. BorRAjo INIESTA: «El status constitucional de los extranjeros", en Estudios sobre la Constitución Española. Homenaje al Profesor E. García de Enterría, tomo II, Madrid, Civitas, 1991, pág. 700. J. L. PIÑAR MAÑAS: «El derecho a la libertad de residencia y circulación de los extranjeros en el territorio nacional", Revista de Administración Pública, núm. 93, septiembre-diciembre, 1980, pág. 199. J. DE EsteBAN y L. LóPEZ GuerRA: El Régimen Constitucional Español, vol. I, Barcelona, Ed. Labor, 1980, pág. 139. L. SÁNCHEZ 
recho de sufragio activo y pasivo en favor de "los ciudadanos españoles". El carácter de fundamentales que se reconoce a los derechos de la sección primera del Capítulo II (incluidos, por lo tanto, los derechos políticos), a juicio de la citada autora, "permite reconocer, en principio, a los extranjeros los mismos derechos y libertades que a los nacionales...Pero en otros derechos cabe una diferencia de tratamiento. Así, hay derechos que no pertenecen en modo alguno a los extranjeros, como los de participación política en los ámbitos regional y nacional..." ${ }^{95}$.

\section{Una propuesta alternativa de reforma constitucional}

El art. 8B del Tratado de Unión Europea acordado en Maastricht el 10 de diciembre de 1992 por los Jefes de Estado y de Gobierno de la Comunidad Europea, exige por tanto una reforma de la Constitución Española que sea conforme al Tratado, a los antecedentes comunitarios, al Derecho Comparado ${ }^{96}$ y a la evolución histórica de la institución del sufragio en su proceso de continua democratización y en justa correspondencia con lo que C. EMERI denomina la umaximisation d'une citoyenneté universelle et égale" ${ }^{97}$. Pero esta reforma deberá alejarse de la voluntad consti-

AgEStA: Sistema político de la Constitución Española de 1978, Madrid, ed. Revista de Derecho Privado, 1991, pág. 184, 188 y 191. J.M. Serrano AlberCa: Comentarios a la Constitución, dir. Garrido Falla, Madrid, Civitas, 1985, pág. 218. J.A. SANTAMARIA: Comentarios a la Constitución, dir. Garrido Falla, Madrid, Civitas, 1985, págs. 443 a 447. R. EnTREna Cuesta: Comentarios a la Ley Orgánica del Régimen Electoral General, dir. L.M. Cazorla Prieto, Madrid, Civitas, 1986, pág. 1463. A. Cano MatA: "El derecho de sufragio activo y pasivo en las elecciones por sufragio universal directo. Regulación de la Ley Orgánica del Régimen Electoral General", Revista de Derecho Público, núm. 110, 1988, pág. 15.

95 R. SÁNCHEZ FERRIZ, op. cit., págs. 142 y 143.

96 Sobre la evolución de la institución del sufragio véanse: N. PÉrez-SERRANo, op. cit., págs. 339 a 341 y R. SMEND: Constitución y Derecho Constitucional, Madrid, Centro de Estudios Constitucionales, 1985, págs. 3 a 25.

En el proceso permanente de ampliación del derecho de sufragio en favor de los extranjeros cabe tener en cuenta, por ejemplo en el Reino Unido, la recomendación del Select Committee on the european communities de la Cámara de los Lores en favor de la propuesta de Directiva de la Comunidad Europea sobre el derecho de voto en las elecciones municipales (Voting rights in local elections, Select committee on the european communities, House of Lords, London, 6 february 1990.

Sobre las posiciones políticas al respecto en Francia véase: B. TRICor y R. HADAS-LeBeL: Les institutions politiques françaises, Paris, Dalloz, 1985, pág. 189.

97 C. EMERI: “Elections et référendums», en Traité de science politique. Les régimes politiques contemporains, dir. M. Grawitz y J. Lega, Paris, Presses Univer- 
tuyente que informó la cláusula limitativa del art. 13.2 basándose, como señala MARTÍNEZ CUADRADO, en la renuncia inequívoca a "cláusulas de apertura al derecho internacional y europeo, debido a la influencia del momento en que se generó un primer consenso posguerra civil y a la visión todavía dominante de los expertos en derecho estatal nacional frente a la más abierta de juristas y especialistas en la evolución proyectiva del derecho europeo" 98 .

Nuestra propuesta de reforma constitucional deberá tener en cuenta las siguientes premisas:

- La superación progresiva de la "dicotomía nacional-extranjero» ${ }^{99}$, el divorcio entre ciudadanía y nacionalidad ${ }^{100}$ y el carácter "absolutamente desfasado" ${ }^{101}$ de la nacionalidad como requisito para ostentar la titularidad del derecho de sufragio.

- El art. 8B del Tratado de Unión Europea reconoce el derecho de sufragio activo $y$ pasivo a los nacionales de Estados miembros de la Comunidad Europea que residan en España en las elecciones municipales y europeas pero ello no debe, en un mundo de ritmos históricos acelerados $y$ en permanente cambio, impedirnos prever otras posibi-

sitaires de France, 1985, pág. 318. Continúa señalando Claude Emeri: "Encore vivances de nos jours, parce que s'appuyant sur l'idée de souveraineté de l'Etat, les règles que réservent le droit de vote aux seuls nationaux. On se souvient qu'elles sont contradictoires avec l'universalisme proclamé par le droit politique libéral et qu'en son temps la Révolution française - "ici commence le paus de la liberté»accorda la citoyenneté "à tout étranger qui... domicilié en France depuis une année, y vit de son travail, ou acquiert une propiété, ou épouse une française, ou adopte un enfant, ou nourrit un vieillard, tout étranger en fin qui sera jugé par le Corps législatif avoir bien mérité l'humanité" (Constitution du 24 juin 1793, art. 5)" (op. cit., págs. 319 y 320 ).

98 M. Martinez CuAdrado: "Maastricht y la Constitución", El País, 7 de febrero 1992.

99 M. DíEZ DE VELASCO: Instituciones de Derecho Internacional Público, Madrid, Ed. Tecnos, 1982, pág. 377.

100 B. ETIENNE: "The question of european citizenship", en Contemporary European affairs, Oxford, vol. 2, núm. 3, 1989, pág. 105, En el mismo sentido, A. CHUECA SANCHO: Los Derechos Fundamentales en la Comunidad Europea, Barcelona, Ed. Bosch, 1989, pág. 388.

101 Cita de F. CarReras y J.M. Vallés (Las elecciones, Barcelona, 1977), en A. Torres del Moral, op. cit., pág. 115. Similar posición adopta E. Pérez Vera: "Art. 13. Extranjerían, en Comentarios a las Leyes Políticas, dir. Ó. Alzaga, tomo Il, ed. Revista de Derecho Privado, pág. 237. 
lidades (elecciones autonómicas ${ }^{102}$ o, ¿por qué no?, generales) a fin de evitar, en el futuro, nuevas reformas innecesarias ${ }^{103}$.

- El art. 23 de la Constitución reconoce el derecho de sufragio activo y pasivo a los ciudadanos españoles $y$, por lo tanto, ningún ciudadano español podrá verse privado de este derecho, pero, en modo alguno, declara la "exclusividad" de este derecho en favor de los ciudadanos españoles.

- El art. 13.2, por contra, sí declara la uexclusividad» del derecho de sufragio en favor de los ciudadanos españoles, salvo el derecho de sufragio activo en las elecciones municipales, pero, por ubicarse en el capítulo primero del Título I, fue voluntad del constituyente que su hipotética reforma siguiera el procedimiento general (art. 167 en relación con el 168).

- El art. 8B del Tratado de Unión Europea no atribuye al ejercicio de competencias derivadas en la Constitución a ninguna organización o institución internacional sino que declara un derecho en favor de los «ciu-

102 La doctrina ha negado tajantemente que el actual art. 13.2 de la Constitución permita que los extranjeros residentes en España gocen del derecho de sufragio en las elecciones de las Asambleas Legislativas de las Comunidades Autónomas; J.M. SerRano Alberca: Comentarios a la Constitución, dir. Garrido Falla, Madrid, Civitas, 1985, pág. 228 y E. SAGARRA I Trías, op. cit., págs. 134 y 135. Este último, sin embargo, advierte que si las Comunidades Autónomas, en el marco de sus competencias, creasen órganos intermedios entre la Asamblea Legislativa y el municipio sí cabría el reconocimiento de este derecho para la participación en la elección indirecta de éstos órganos - ej. las comarcas creadas por la Ley 6/1987, de 4 de abril, sobre organización comarcal de Catalunya (DOG, núm. 826 , de 8 de abril de 1987, pág. 1353) - o de las Diputaciones Provinciales.

No obstante, es frecuente, a los efectos de concesión de este derecho a los extranjeros, que se diferencia ente los derechos "políticos" de participación (elecciones a instituciones de ámbito territorial como Cortes, Asambleas y Autonómicas y Corporaciones Locales o en procesos referendarios) y elecciones "no políticas" (L. LóPEZ GuerRA: Derecho Constitucional, VV.AA., Valencia, Ed. Tirant lo Blanch, 1991, pág. 263). También se distingue entre «elecciones políticas" y elecciones administrativas (municipales) concediendo, en este último caso, el derecho de sufragio a los extranjeros (P. BISCARETTI DI RufFIA, op. cit., pág. 309). Por último, MASCLET afirma que los extranjeros no dispondrán del derecho de sufragio en las "elecciones políticas" pero si (por ej. en Francia) en las "elecciones profesionales" (elección de representantes de personal en las empresas o de estudiantes en los consejos de administración de los centros regionales de obras escolares o universitarias) como ha declarado el Consejo de Estado francés (J-CL. MASCLET: Droit électoral, Paris, Presses Universitaires de France, 1989, pág. 46.

103 Al respecto no cabe sino recordar la profética intervención, ya reproducida en este trabajo, de Peces-Barba durante los debates constituyentes. 
dadanos europeos" por lo que, por muy paradójico que resulte ${ }^{104}$, su ratificación, de acuerdo con el art. 95, requerirá la previa revisión constitucional.

- El art. 13.2 no sólo permite el derecho de sufragio activo en las elecciones municipales de los extranjeros "comunitarios" que residan ë́n España sino que también lo atribuye a los extranjeros "extracomunitarios". Acertada previsión que una futura reforma constitucional debería respetar de acuerdo con los principios de reciprocidad e igualdad.

Por las razones expuestas únicamente debería ser reformado el artículo 13.2 de la Constitución que adoptaría el siguiente tenor:

"Los extranjeros gozarán en España del derecho de sufragio activo y pasivo en los términos que establezcan los tratados y la ley” ${ }^{105}$.

104 La paradoja reside en que, en virtud del principio de primacía del Derecho Comunitario sobre el Derecho Interno (texto constitucional incluido) reiterado por la jurisprudencia del Tribunal de Justicia de las Comunidades Europeas, una norma comunitaria que reconociese estos derechos hubiese causado efectos directos en nuestro ordenamiento interno, mientras que un Tratado Internacional acordado por los mismos Estados miembros de la Comunidad Europea requiere, para que adquieran vigencia los derechos que reconoce, la reforma constitucional previa a su ratificación.

105 Desde la celebración en Logroño, del 27 al 30 de abril de 1992, del Congreso sobre la reforma constitucional hasta el momento de dar este trabajo a la imprenta, se han visto resueltas las dudas doctrinales y políticas suscitadas sobre la necesidad de reforma constitucional previa a la ratificación del Tratado de Maastricht.

El 1 de julio de 1992 el Tribunal Constitucional emitió una Declaración (BOE núm. 177, 24-VII-1992), que, entre otras consideraciones, ponía de manifiesto la contradicción existente entre el art. $8 \mathrm{~B}$ TUE y el art. 13.2 de la Constitución y la exigencia de que los poderes públicos procedieran a la reforma de éste mediante el procedimiento previsto en el art. 167 del texto constitucional. Para dar cumplimiento a la Declaración vinculante del Tribunal, las Cortes Generales procedieron a la reforma del precepto citado y el Rey sancionó y promulgó la reforma constitucional que entraría en vigor el mismo día de su publicación en el $B O E$, es decir, el 28 de agosto de 1992. El texto reformado del art. 13.2 de la Constitución ofrece el siguiente tenor: "Solamente los españoles serán titulares de los derechos reconocidos en el art. 23, salvo lo que, atendiendo a criterios de reciprocidad, pueda establecerse por tratado o ley para el derecho de sufragio activo y pasivo en las elecciones municipales".

Con posterioridad a la redacción de este trabajo han sido publicados dos estudios que, por su relación con el tema expuesto, merecen ser señalados: E. ARNALDo AlCuBILLA. "El derecho de sufragio de los extranjeros en las elecciones locales", $R E D C$, núm. 34, 1992, y J. F. López AGUiLAR: "Maastricht y la problemática de la reforma de la Constitución", REP, núm. 77, 1992. 